\title{
Nutrient release from an exposed intertidal sand flat
}

\author{
Markus Billerbeck $^{1, *}$, Ursula Werner ${ }^{1}$, Katja Bosselmann $^{1}{ }$, Eva Walpersdorf ${ }^{2}$, \\ Markus Huettel ${ }^{3}$ \\ ${ }^{1}$ Max Planck Institute for Marine Microbiology, Celsiusstrasse 1, 28359 Bremen, Germany \\ ${ }^{2}$ Oceanlab, University of Aberdeen, Main Street, Newburgh, Aberdeenshire AB41 6AA, UK \\ ${ }^{3}$ Department of Oceanography, Florida State University, West Call Street, Tallahassee, Florida 32306-4320, USA
}

\begin{abstract}
We studied pore water seepage and associated nutrient release in the Janssand intertidal sand flat (North Sea) during exposure at low tide. The hydraulic gradient developing at ebb tide between the pore water level in the elevated sand flat and the water level in the tidal gully generated interstitial water flows toward the seepage zone with velocities ranging from 0.5 (March) to $0.9 \mathrm{~cm} \mathrm{~h}^{-1}$ (July). Pore water was discharged from an approximately $20 \mathrm{~m}$ wide zone near the seaward margin of the flat at rates of 2.4 (March) and $4.2 \mathrm{l} \mathrm{m}^{-2} \mathrm{~d}^{-1}$ (July). Nutrient and dissolved inorganic carbon (DIC) concentrations of the seepage water exceeded those measured in the pore water of the upper section of the flat by $10-$ and 5 -fold, respectively. Nutrient effluxes through seepage reached 1100 and $7600 \mu \mathrm{mol} \mathrm{m}^{-2} \mathrm{~d}^{-1}$ for $\mathrm{NH}_{4}, 280$ and $2500 \mu \mathrm{mol} \mathrm{m}{ }^{-2} \mathrm{~d}^{-1}$ for $\mathrm{PO}_{4}$ and 140 and $1700 \mu \mathrm{mol} \mathrm{m}^{-2} \mathrm{~d}^{-1}$ for $\mathrm{Si}(\mathrm{OH})_{4}$ in March and July, respectively. Benthic flux chambers revealed that nutrients and DIC were released from the still submerged sediment as soon as the ebb tide exposed the upper section of the elevated flat. A conservative estimate based on our measurements suggests that 1680001 (March) to 294000 l (July) pore water are discharged each day from the sandy northeastern margin of the Janssand ( $3.5 \mathrm{~km}$ length, $\left.70000 \mathrm{~m}^{2}\right)$. Nutrients contained in this water corresponded to $6-25 \mathrm{~kg} \mathrm{~d}^{-1}$ (90 to $350 \mathrm{mg} \mathrm{m}^{-2} \mathrm{~d}^{-1}$ ) carbon mineralized during March and 42-223 $\mathrm{kg} \mathrm{d}^{-1}$ (600 to $3200 \mathrm{mg} \mathrm{C} \mathrm{m}^{-2} \mathrm{~d}^{-1}$ ) during July. Our study indicates that the Janssand intertidal flat does not accumulate organic matter but releases mineralization products that can account for all the organic matter that is potentially filtered through the permeable beds during a tidal cycle. Nutrient fluxes associated with seepage exceeded 5- to 8-fold those fluxes caused by the combined effects of diffusion, advection and bioirrigation during inundation, emphasizing the importance of sand flat drainage to the nutrient cycles in the Wadden Sea.
\end{abstract}

KEY WORDS: Intertidal flat · Drainage - Pore water flow velocity · Filtration · Nutrient flux Resale or republication not permitted without written consent of the publisher

\section{INTRODUCTION}

Fine to medium sands prevail in the intertidal regions of the Wadden Sea, covering a total area of ca. $13000 \mathrm{~km}^{2}$ along the Dutch, German and Danish coasts (Flemming \& Ziegler 1995, van Beusekom \& de Jonge 2002). The relatively high permeability of these sands $\left(10^{-12}\right.$ to $\left.10^{-11} \mathrm{~m}^{2}\right)$ allows inflow of water through the interstices as soon as pressure gradients caused by currents or water level changes are present. During inundation, the pore water exchange transports solutes (Huettel et al. 1998) and particles (Huettel et al. 1996, Pilditch et al. 1997) into and out of the upper layers of permeable sediment. Through the enhanced exchange of organic matter, electron acceptors and metabolic products (Ziebis et al. 1996, Huettel et al. 1998), such permeable sands become sites of high organic matter turnover (Huettel \& Rusch 2000, D'Andrea et al. 2002). During ebb tide, pressure gradients develop between the pore water level within elevated, exposed sand flats and the decreasing water level of the Wadden Sea. In these sands, the pore water table drops slower than the seawater level (Nielsen 1990) because of the sediment's hydraulic impedance and capillary forces, and the ensuing pressure gradient leads to water release that fills the numerous drainage channels typi- 
cal of intertidal flats (Nielsen 1990, Horn 2002). Such discharge of pore water has been recognized as an ecologically important process in studies covering coastal, submarine, groundwater discharge (Simmons 1992, Moore 1996, Taniguchi \& Iwakawa 2004), wave dominated beaches (McLachlan \& Illenberger 1986, Uchiyama et al. 2000, Ullman et al. 2003) and salt marshes (Howes \& Goehringer 1994, Osgood 2000, Jahnke et al. 2003). For tide dominated intertidal flats, however, studies on drainage and associated solute releases are scarce. Le Hir et al. (2000) estimated from runnel-runoff velocities that intertidal mud flats on the French and British coasts discharged roughly $10 \mathrm{l} \mathrm{m}^{-2}$ tide $^{-1}$. In a tidal flat in Tokyo Bay, drainage has been suggested as a possible mechanism causing a drop in sedimentary water content during exposure (Usui et al. 1998). In contrast, Kuwae et al. (1998) concluded that pore water release in another intertidal flat in Tokyo Bay was small because the sediment remained nearly saturated during exposure. Likewise, Drabsch et al. (1999) suggested that tidal pumping and total water flux in a tidal flat (Manukao Harbour, New Zealand) was small because pore water flow velocities ranged only between 0.2 and $4.0 \mathrm{~cm} \mathrm{~d}^{-1}$. However, visible pore water seepage from intertidal sand flats in the North Sea indicates that drainage may produce significant pore water release in more steeply sloping flats. Therefore, we initiated the present study, which investigated the magnitude of pore water release and implications of this drainage for sedimentary nutrient and dissolved inorganic carbon (DIC) release in permeable intertidal sand flats. Because benthic microalgae act as biological nutrient filters at the sediment-water interface (Sundbäck et al. 2000), we also assessed the effect of these organisms on nutrient release during inundation.

\section{MATERIALS AND METHODS}

Study site. The study was conducted during 2 field campaigns (July 2003 and March 2004) on the northeastern margin of the intertidal Janssand sandflat situated landward of the barrier island of Spiekeroog, North Sea (53 $44^{\prime} 07^{\prime \prime} \mathrm{N}, 007^{\circ} 41^{\prime} 57^{\prime \prime} \mathrm{E}$ ) (Fig. 1). Tides in this area are semi-diurnal, and the Janssand (11 km² area) is covered by approximately 1.5 to $2 \mathrm{~m}$ of water during high tide, becoming exposed to air for about 6 to $7.5 \mathrm{~h}$ during low tide. The Janssand tidal flat is almost level, except at the margin where the sediment surface slopes $\left(1.6 \mathrm{~cm} \mathrm{~m}^{-1}\right.$ over ca. $80 \mathrm{~m}$, Fig. 2). We chose 4 study sites (A to D in Fig. 2), with most measurements conducted at the 'lower sand flat' site (Site D) near the edge of the Janssand and at the 'upper sand flat' site (Site A) about $45 \mathrm{~m}$ upslope from the mean low water line. All measurements and samplings are listed in Table 1, together with their respective locations on the tidal flat and associated tidal range. The Janssand is characterized by well sorted $(\sigma<0.38 \mathrm{phi})$, fine quartz sands with a mean grain size of $176 \mu \mathrm{m}$ (assessed through dry-sieving). On the upper sand flat, permeability of the sediment surface layer (upper $15 \mathrm{~cm}$ ), determined by constant head permeametry, is $7.2 \times 10^{-12} \mathrm{~m}^{2}\left(\mathrm{SD} \pm 0.6 \times 10^{-12} \mathrm{~m}^{2}, \mathrm{n}=6\right.$, July 2003), which permits advective pore water flows (Huettel et al. 2003). At the lower sand flat site, the same layer is less permeable $\left(5.2 \times 10^{-13} \mathrm{~m}^{2}[\mathrm{SD} \pm 0.3 \times\right.$ $\left.10^{-13} \mathrm{~m}^{2}, \mathrm{n}=6\right]$ ), because of imbedded mud lenses. Macrofaunal abundances are relatively low at the study site (Hertweck 1995). The Spiekeroog tide gauge within $2 \mathrm{~km}$ of the study site provided the data on water level changes.

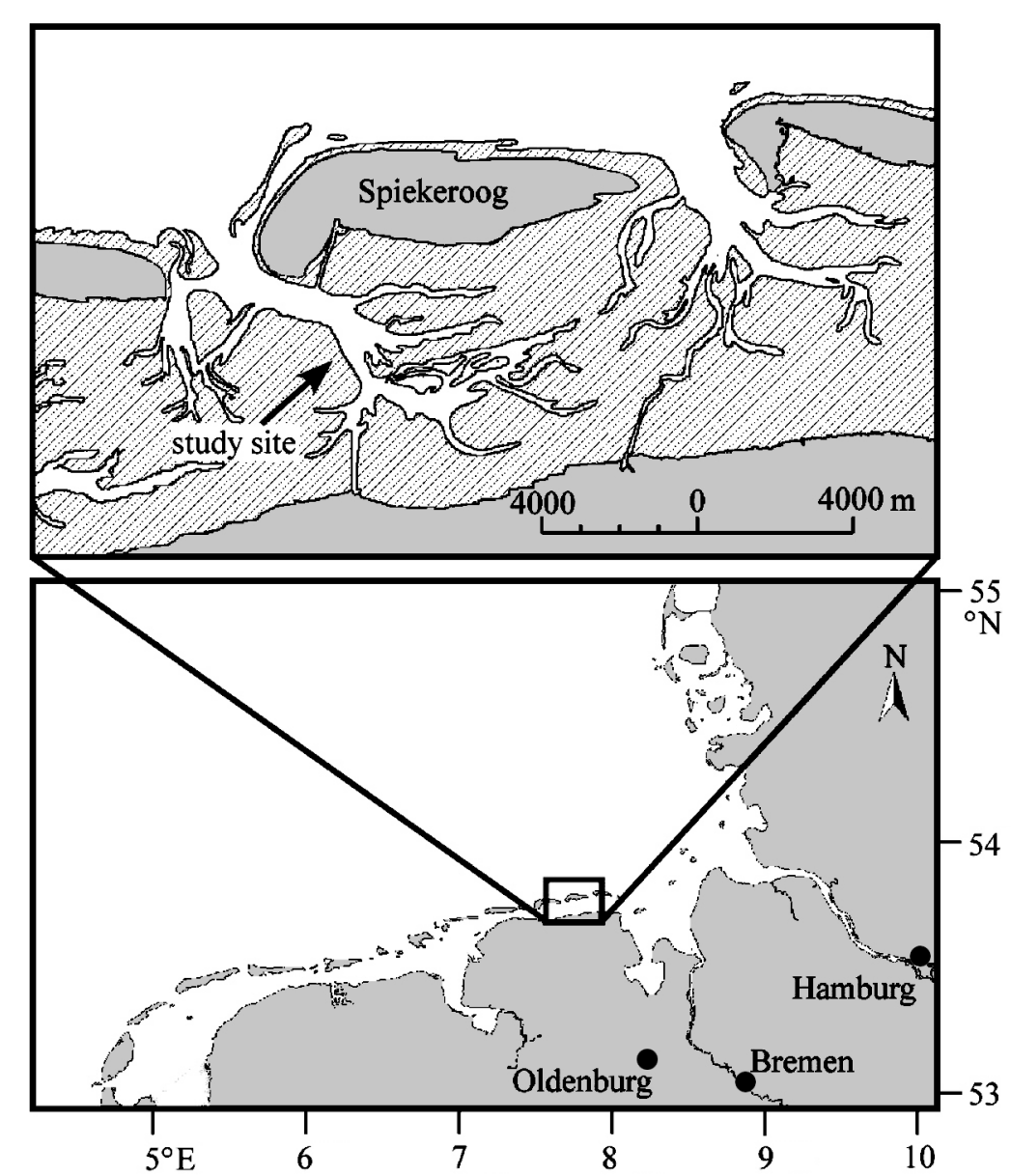

Fig. 1. Location of the study site, near the island of Spiekeroog, North Sea, Germany 


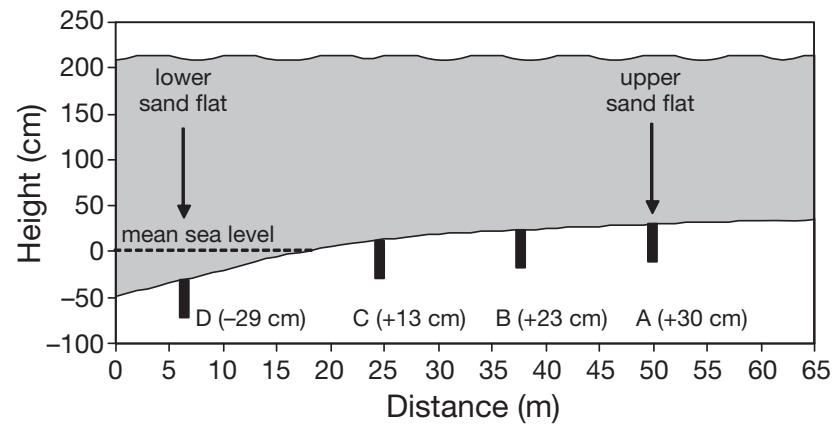

Fig. 2. Janssand tidal flat topography, as surveyed during July 2003, showing positions (cm) of Study Sites A-D relative to mean sea level. Shading indicates the mean high water; dashed line at zero water height marks the position of mean low water line during July 2003. An additional 10 to $15 \mathrm{~m}$ of the tidal flat was exposed during the March 2004 campaign due to wind conditions

Pore water level. To assess fluctuations of the pore water level within the sediment with change in the tidal water level, 4 acrylic pipes $(20 \mathrm{~cm}$ long, $36 \mathrm{~mm}$ diameter) were vertically inserted into the sediment on a transect (A-D in Fig. 2) from the upper sand flat site (A) toward the lower sand flat site (D). The open lower ends of the pipes were covered with nylon mesh $(63 \mu \mathrm{m})$ and their open upper ends were level with the sediment surface. The water table in the pipes was measured to the nearest $1 \mathrm{~mm}$ with a ruler throughout exposure of the respective sites, at 1 to $60 \mathrm{~min}$ intervals (Table 1).

Pore water flow velocity. The horizontal flow velocity of pore water was measured at the upper sand flat site by following the passage of a fluorescent dye tracer through the sediment with a buried linear array of 6 fiberoptic sensors, as described in Precht \& Huettel (2004) (Fig. 3). The tracer solution was prepared by adding fluorescein dye to filtered seawater to an end concentration of $100 \mathrm{mg} \mathrm{l}^{-1}$ and adjusting it to the local pore water density. Prior to the first measurement, fluorescein dye solution was injected with a syringe into the sand, and subsequently dug out to visually determine the main flow direction of the pore water. Then a small incision was cut into the sediment at low tide to the desired depth, and the setup was carefully inserted and pushed horizontally several centimeters into the undisturbed part of the sediment. The sensor array orientation was horizontal to the sediment surface and roughly perpendicular to the low water line; other orientations did not show any measurable pore water flow. During the July 2003 campaign, pore water flow velocities were measured at 2,5 and $10 \mathrm{~cm}$ sediment depth throughout exposure. These measurements were extended by four $10 \mathrm{~cm}$ intervals to a sediment depth of $50 \mathrm{~cm}$ during the March 2004 campaign. An additional measurement was conducted at $5 \mathrm{~cm}$ sediment depth about $30 \mathrm{~m}$ upslope on the upper sand flat site (+6 cm height) during the March campaign. Some measurements were continued during inundation of the tidal flat until re-exposure. All pore water flow velocity measurements were conducted during the transition from mean tide to neap tide for both campaigns. The average pore water flow velocity was calculated for all measurements from the time interval between the geometric centroids of the signal curves at consecutive sensors (Fig. 3). The average and standard deviation of flow velocity were derived for each deployment from individual velocity calculations between adjacent sensors in the 6-sensor array.

Table 1. Sampling and in situ measurements made during July 2003 and March 2004 field campaigns. Also shown are sites A to D where measurements were made, their tidal range, and their respective positions on the tidal flat. Positions of the sites A to D relative to mean sea level were $+30,+23,+13$, and -29 , respectively (Fig. 2). Seepage measurements were made using open and rhombic meters; chamber measurements assessed solute fluxes and benthic primary production during inundation. Further details in 'Materials and methods'

\begin{tabular}{|c|c|c|c|c|c|c|c|c|}
\hline \multirow{2}{*}{$\begin{array}{l}\text { Date } \\
\text { (dd.mo.yr) }\end{array}$} & \multirow{2}{*}{$\begin{array}{l}\text { Tidal } \\
\text { range } \\
(\mathrm{m})\end{array}$} & \multirow{2}{*}{$\overline{\text { Sediment }}$ Sit } & \multicolumn{3}{|c|}{ ite characteristics } & \multicolumn{3}{|c|}{ In situ measurements } \\
\hline & & & Seawater & $\begin{array}{l}\text { Pore } \\
\text { water }\end{array}$ & $\begin{array}{c}\text { Pore water } \\
\text { level }\end{array}$ & $\begin{array}{l}\text { Pore water } \\
\text { flow velocity }\end{array}$ & Chambers & Seepage \\
\hline 21.07 .2003 & 2.7 & & & & & A: $2 \mathrm{~cm}$ depth & & \\
\hline 22.07 .2003 & 2.6 & & & A & & & & \\
\hline 23.07 .2003 & 2.3 & Topography: A-D & $\mathrm{D}$ & & & & & \\
\hline 25.07 .2003 & 2.2 & & & & & A: $10 \mathrm{~cm}$ depth & & \\
\hline 26.07.2003 & 2.5 & Grain size: A & & & $\mathrm{A}, \mathrm{B}, \mathrm{C}, \mathrm{D}$ & A: $5 \mathrm{~cm}$ depth & & \\
\hline 27.07 .2003 & 2.7 & Permeability: A,D & & & & & & \\
\hline 29.07.2003 & 3.0 & Chl a: A & High tide & & & & A & \\
\hline 30.07 .2003 & 3.2 & Chl a: D & High tide & & & & $\mathrm{D}:-12 \mathrm{~cm}$ & \\
\hline 26.03.2004 & 3.0 & & & & & A: $2 \mathrm{~cm}$ depth & & D: $-21 \mathrm{~cm}$ (open) \\
\hline 27.03 .2004 & 2.8 & & & & & A: $5 \mathrm{~cm}$ depth & & D: $-21 \mathrm{~cm}$ (open) \\
\hline 28.03.2004 & 2.5 & & High tide & & & A: $20 \mathrm{~cm}$ depth & & $\mathrm{D}:-21 \mathrm{~cm},-32 \mathrm{~cm}$ (open) \\
\hline 29.03.2004 & 2.3 & & & & & A: $30 \mathrm{~cm}, 40 \mathrm{~cm}$ depths & & $\mathrm{A}, \mathrm{C}, \mathrm{D}:-21 \mathrm{~cm}$ (open) \\
\hline 30.03 .2004 & 1.9 & & & $\mathrm{~A}, \mathrm{D}$ & & A: $50 \mathrm{~cm}$ depth & & D: $-21 \mathrm{~cm}$ (rhombic) \\
\hline 31.03.2004 & 1.8 & & & & & A+6 cm: $5 \mathrm{~cm}$ depth & & \\
\hline
\end{tabular}




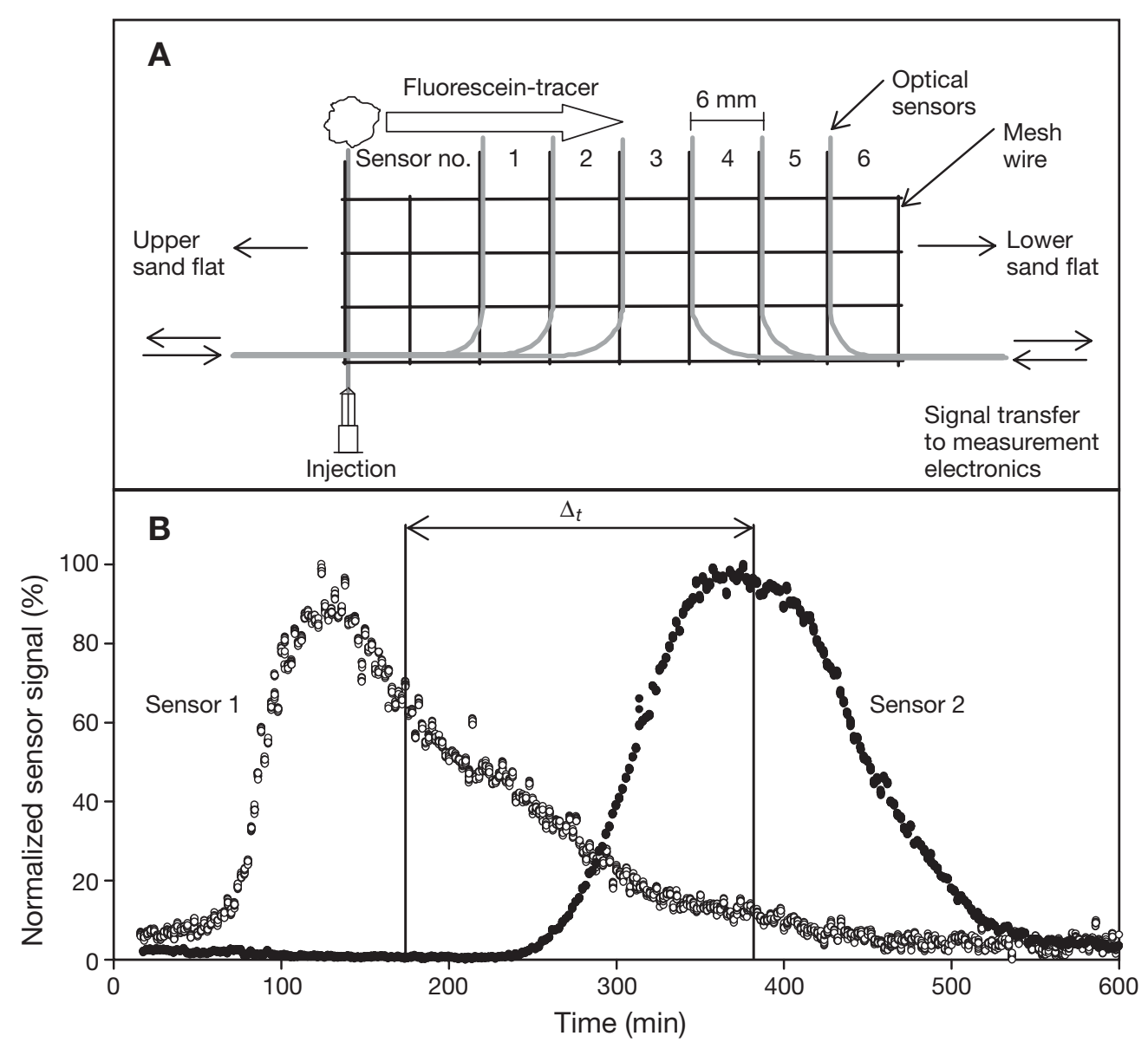

Fig. 3. (A) Setup of the 6 optical sensors used to measure pore water flow velocity (schematic, top view). (B) Fluorescence signals of 2 optical fibers and location of geometric centroids (vertical lines) used to calculate time span $(\Delta t)$ between dye passage at respective sensor tips. Geometric centroids are located at cumulative $50 \%$ of the respective signal curve areas
Pore water seepage. Pore water discharge from the sloping margin of the tidal flat was quantified in March during exposure by measuring the volume of fluid collected at the end of 2 flow barriers (open seepage meter) that guided draining pore water into a container (Fig. 4). The open seepage meter consisted of two $5 \mathrm{~cm}$ wide plastic laths (100 cm length) inserted to a depth of $2 \mathrm{~cm}$ vertically into the sediment, with the 2 laths forming an angle of $130^{\circ}$. The resulting surface-water flowbarrier collected seepage water from a $1.8 \mathrm{~m}$ wide upslope section of the flat. At the meeting point of the 2 plastic laths, a plastic funnel with tubing was attached to collect the seeped pore water into a graduated cylinder. The amount of collected pore water was quantified to the nearest $1 \mathrm{ml}$, and filtered samples were transferred to plastic vials and kept frozen for later nutrient analysis. Up to 3 of these seepage meters were established along a transect (Sites A, C, D) and were ready for measurement within $20 \mathrm{~min}$ of exposure. The zones of pore water discharge upslope of the seepage meters could be identified from the 'glassy' appearance of the surface of the water saturated sediment, and their areal dimensions were recorded throughout the measurements. In order to verify the seepage mea- surements with the open seepage meter, an additional measurement was conducted by inserting 2 additional plastic laths opposite to the open seepage meter, isolating a rhombic area of $0.78 \mathrm{~m}^{2}$ (Fig. 4). A good agreement between the seepage rates $\mathrm{m}^{-2}$ measured with the rhombic and open seepage meters was obtained for discharge zones extending less than $6 \mathrm{~m}$ above the open seepage meter. Discharge rates were calculated by dividing the collected pore water volume per unit time by the respective seepage area (Fig. 4) of the open or rhombic seepage meter.

Chamber flux measurements. During the July 2003 campaign, in situ measurements with stirred cylindrical chambers (19 cm inner diameter) were carried out to measure advective fluxes of oxygen, DIC and nutrients across the sediment-water interface. At the lower sand flat site, the chambers were also used to assess drainage discharge of solutes from the sediment. The chamber measurements were conducted on 2 consecutive days at the upper and lower sand flat sites. We deployed 3 transparent and 3 opaque chambers at each site, permitting assessment of benthic primary production during inundation. At the lower sand flat site, chamber incubations were longer $(8 \mathrm{~h})$ and water 
Fig. 4. Setup of open and rhombic seepage meters on the sloping sand flat. Discharge area was identified from the 'glassy' appearance of sediment surface upslope of the meter (hatched area), and spanned an area of 6 to $13 \mathrm{~m}^{2}$ for the open and $0.78 \mathrm{~m}^{2}$ for the rhombic seepage meters

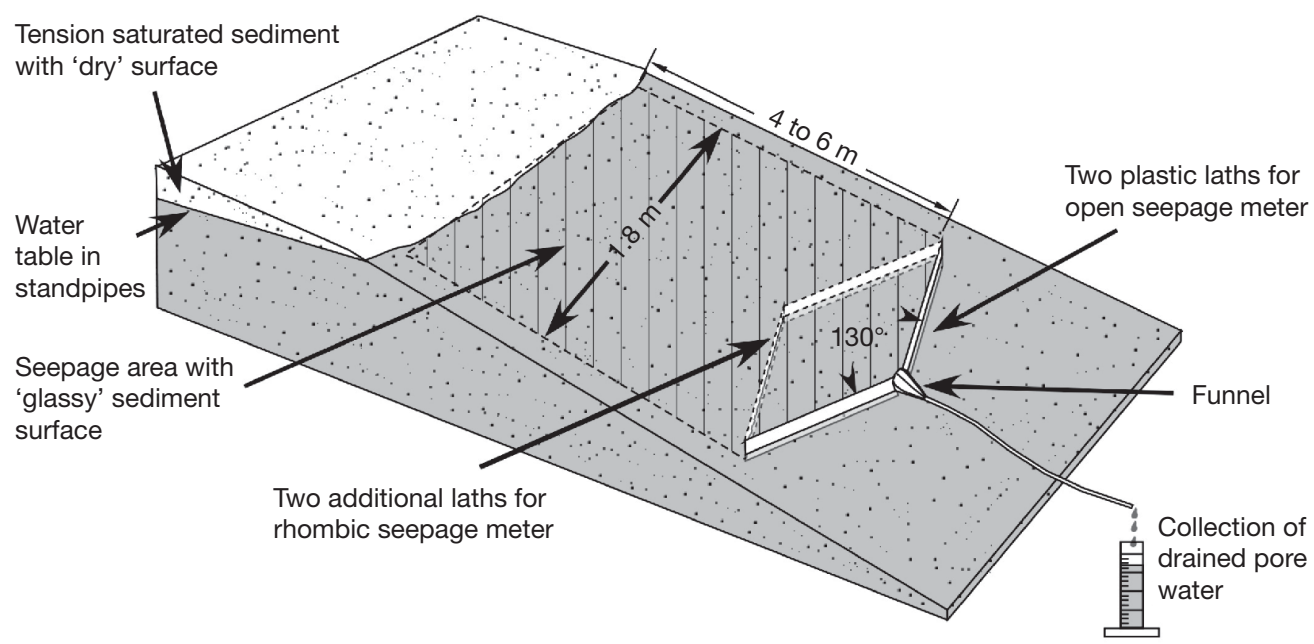

depth deeper $(2.3 \mathrm{~m})$, than at the upper flat (4 $\mathrm{h}$ incubations, $1.5 \mathrm{~m}$ water depth). During the incubation period, water temperature varied by $\leq 1^{\circ} \mathrm{C}$, while concentrations of nutrients, DIC and oxygen in the ambient seawater remained relatively constant. During low tide, the chambers were gently inserted to a sediment depth of $19 \mathrm{~cm}$, and neoprene collars (20 cm diameter) were placed around them to prevent erosion. Upon inundation, the chambers were sealed with acrylic lids, each enclosing a water volume of $3.4 \mathrm{l}$ and a sediment area of $0.028 \mathrm{~m}^{2}$. Inside the chambers, a rotating disc $(15 \mathrm{~cm}$ diameter, $20 \mathrm{rpm}$ ) producing a radial pressure gradient of $0.1 \mathrm{~Pa} \mathrm{~cm}^{-1}$ caused flushing of the upper sediment layer, thus mimicking natural advective pore water exchange (Huettel \& Gust 1992, Huettel \& Rusch 2000). Advective tracer and solute fluxes caused by this very low pressure gradient (corresponding to a gradient created by flow of $10 \mathrm{~cm} \mathrm{~s}^{-1}$ at $10 \mathrm{~cm}$ above the bed interacting with a sediment ripple of $0.5 \mathrm{~cm}$ height) should be considered conservative. Each lid had a sampling port and a small opening with a $1 \mathrm{~m}$ Tygon ${ }^{\mathrm{TM}}$ tubing coil attached to it to allow pressure equilibration between chamber and surrounding water and inflow of discharged pore water into the chambers. Oxygen concentrations inside each chamber were monitored every 2 min for $20 \mathrm{~s}$ with fiberoptic optodes (Klimant et al. 1995) inserted through the chamber lid. After closing the chambers, $20 \mathrm{ml}$ of a $3 \mathrm{~mol} \mathrm{l}^{-1} \mathrm{NaBr}$ inert tracer solution was injected into 1 dark and 1 light chamber for the assessment of the depth of advective fluid exchange between overlying water and sediment (Forster et al. 1999). After the bromide tracer had mixed with the chamber water for $15 \mathrm{~min}$, all chambers were sampled at hourly intervals (when water level and currents permitted). At each sampling, samples of ambient seawater were taken, and a total of $80 \mathrm{ml}$ of water was drawn with a syringe from each chamber, of which the first 20 $\mathrm{ml}$ were discarded to compensate for the sampling tube volume $(15 \mathrm{ml})$. At the end of the incubations, with the water level still above the chambers, sediment cores from the chambers treated with bromide tracer were retrieved with cut-off $60 \mathrm{ml}$ syringes. The sediment cores were sliced into $0.5 \mathrm{~cm}$ sections within $30 \mathrm{~min}$ after retrieval and kept frozen until analysis. Benthic chamber measurements could not be carried out during March due to adverse weather conditions.

Sampling and analyses. For sedimentary chlorophyll $a$ determination, samples of the upper $5 \mathrm{~cm}$ of the sand were divided into $0.5 \mathrm{~cm}$ sections for analysis according to Lorenzen (1967). For characterization of ambient seawater, samples collected at high tide and samples from gullies (ebb tide) were collected in plastic centrifuge tubes (glass vials for DIC and dissolved organic carbon, DOC) and filtered through $0.2 \mu \mathrm{m}$ nylon syringe filters. Aliquots were either kept frozen (for nutrients, DOC) or preserved with mercury chloride (for DIC analysis). For POC and PN contents, samples were filtered onto pre-combusted Whatman ${ }^{\circledR}$ GFF filters and kept frozen. For pore water nutrient and DIC determinations, sediment cores were collected with $36 \mathrm{~mm}$ core liners shortly after exposure of the study sites and sectioned within an argon-flushed glove box to a depth of $20 \mathrm{~cm}$ at $1 \mathrm{~cm}$ intervals. Equivalent slices from 4 sediment cores were pooled and transferred to a small pressure container with an inert gas inlet and a pore water outlet. By flushing the container ca. $20 \mathrm{~s}$ with argon gas, the pore water was separated from the sediment matrix. After filtration through $0.2 \mu \mathrm{m}$ nylon syringe filters, aliquots were frozen for nutrient analysis or preserved with saturated mercury chloride solution for subsequent DIC analysis. Bromide in the pore water was analyzed by ion chromatography with a Waters ${ }^{\circledR}$ anion-exchange column, using $\mathrm{NaBr}$ as a standard for calibration. Filters for POC and PN analysis were treated with a few drops of $1 \mathrm{~mol} \mathrm{l}^{-1} \mathrm{HCl}$ to remove inorganic carbon, prior to analysis on a Heraeus ${ }^{\circledR}$ CHNO- 
rapid elemental analyzer with sulfanilamide as calibration standard. Nutrient analyses of silicate, phosphate, ammonium, nitrate and nitrite were performed spectrophotometrically with a Skalar continuous-flow-analyzer according to Grasshoff et al. (1999). DIC was determined by flow injection analysis (Hall \& Aller 1992) or coulometric titration on a UIC CM5012 (for chamber water). Seawater DOC analysis was performed by high temperature, catalytic oxidation on a ShimadzuTM TOC5050A analyzer and obtained by subtracting the measured DIC concentration from the measured total DC. Oxygen concentrations of chamber water were determined by Winkler titration and used for calibration of the chambers' oxygen optodes (for details see Klimant et al. 1995, Holst et al. 1997). Dilution of the chamber waters due to sampling was corrected by adding the difference of the solute inventory between the sampled and replaced volume to the chamber volume solute inventory. Solute fluxes were estimated by linear regression on concentration changes over time, or from start and end concentrations when linear regression was not applicable. Pore water concentrations and flux data were analyzed with a Wilcoxon-Mann-Whitney nonparametric $U$-test for pairwise comparisons at a $95 \%$ confidence level $(\mathrm{p}<0.05)$.

\section{RESULTS}

\section{Pore water level}

The water level in the sediment changed when the Janssand became exposed at ebb tide (Fig. 5). At Sites A and B on the upper sand flat, the pore water level remained at the sediment surface during the first $2 \mathrm{~h}$ of exposure and dropped gradually thereafter, reaching its lowest point approximately $1.5 \mathrm{~h}$ after low tide. The pore water level then increased again with the rising tide, but never reached the sediment surface until re-inundation. At Site $\mathrm{C}$, the pore water level remained high and did not drop at all at the lower sand flat position, Site D. At Site D, a pore water level at times above sediment elevation cannot be ruled out, as the open end of the standpipe was level with the sand surface. The maximum measured difference in pore water level between the upper (Site A) and lower (Site D) sand flat was $46 \mathrm{~cm}$ over a horizontal distance of $4300 \mathrm{~cm}$.

\section{Pore water flow velocity}

The fiberoptical measurements revealed pore water flows directed toward the low water line over the measured sediment depth of $50 \mathrm{~cm}$ during exposure

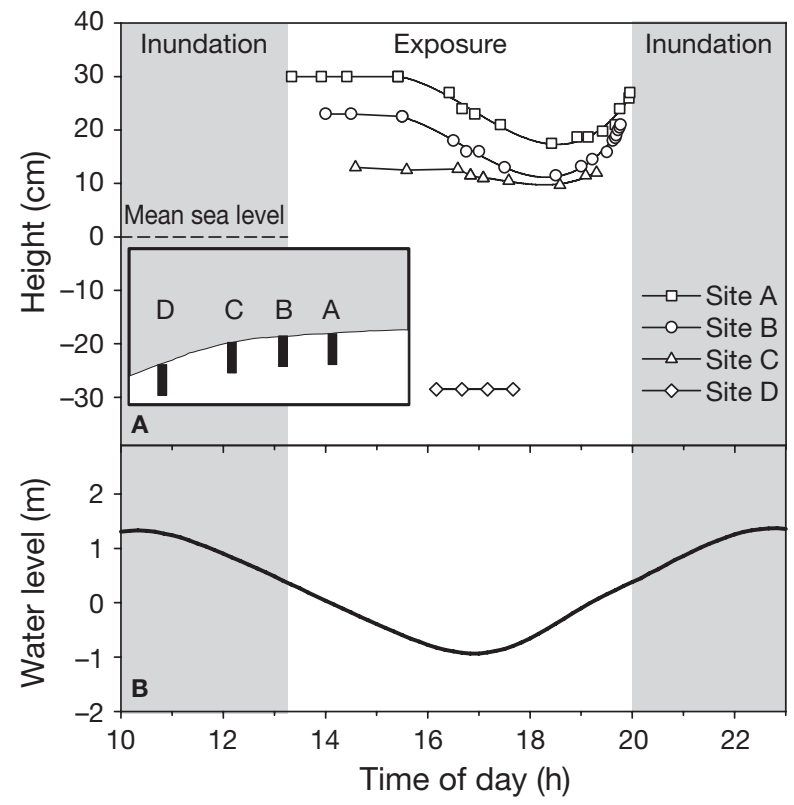

Fig. 5. (A) Response of pore water level, relative to mean sea level, to fluctuation in the tidal water level at Sites A-D (accuracy of $\pm 1 \mathrm{~mm}$ ) during average tidal range (pore water levels may differ for other tidal ranges). Trend lines were manually drawn through the data sets. Inset: schematic representation of locations of respective measurement sites on tidal flat (see also Fig. 2). Shading marks inundation period of upper sand flat site (Site A). (B) Tidal water level based on mean sea level

(Table 2). During July 2003, an average pore water flow velocity of $0.86 \mathrm{~cm} \mathrm{~h}^{-1}$ was measured, with similar velocities between 2 and $10 \mathrm{~cm}$ sediment depths (Table 2). This pore water flow started after the exposure of the tidal flat and continued for $6.5 \mathrm{~h}$ until the measuring position became inundated again. After submergence of the measuring position, a steady fluorescence signal remained for the seaward sensor during the entire inundation period (Fig. 6), and decreased rapidly once the tidal flat became exposed again. This

Table 2. Pore water flow velocities at different sediment depths at upper sand flat site during the July and March campaigns. Flow velocities at respective depths are given as average of measurements between consecutive sensors $\pm \mathrm{SD}(\mathrm{n}=3-5)$

\begin{tabular}{|c|c|c|}
\hline \multirow{2}{*}{$\begin{array}{l}\text { Sediment } \\
\text { depth }(\mathrm{cm})\end{array}$} & \multicolumn{2}{|c|}{ Flow velocity $\left(\mathrm{cm} \mathrm{h}^{-1}\right)$} \\
\hline & July 2003 & March 2004 \\
\hline 2 & $0.87 \pm 0.32$ & $0.68 \pm 0.27$ \\
\hline 5 & $0.74 \pm 0.23$ & $0.61 \pm 0.11$ \\
\hline 10 & $0.98 \pm 0.13$ & \\
\hline 20 & & $0.58 \pm 0.25$ \\
\hline 30 & & $0.62 \pm 0.39$ \\
\hline 40 & & $0.45 \pm 0.17$ \\
\hline 50 & & $0.32 \pm 0.06$ \\
\hline Average & 0.86 & 0.54 \\
\hline
\end{tabular}


Fig. 6. (A) Tracer signal curves from velocity measurements of pore water flow in $2 \mathrm{~cm}$ sediment depth at the upper sand flat site in July 2003 (see also Table 2). Normalized signals (\% of maximum signal) of 5 consecutive sensors are shown during exposure (white) and inundation (shaded) of the measuring position; Sensor 6 data could not be shown because of excessive data noise. (B) Tidal water level based on mean sea level

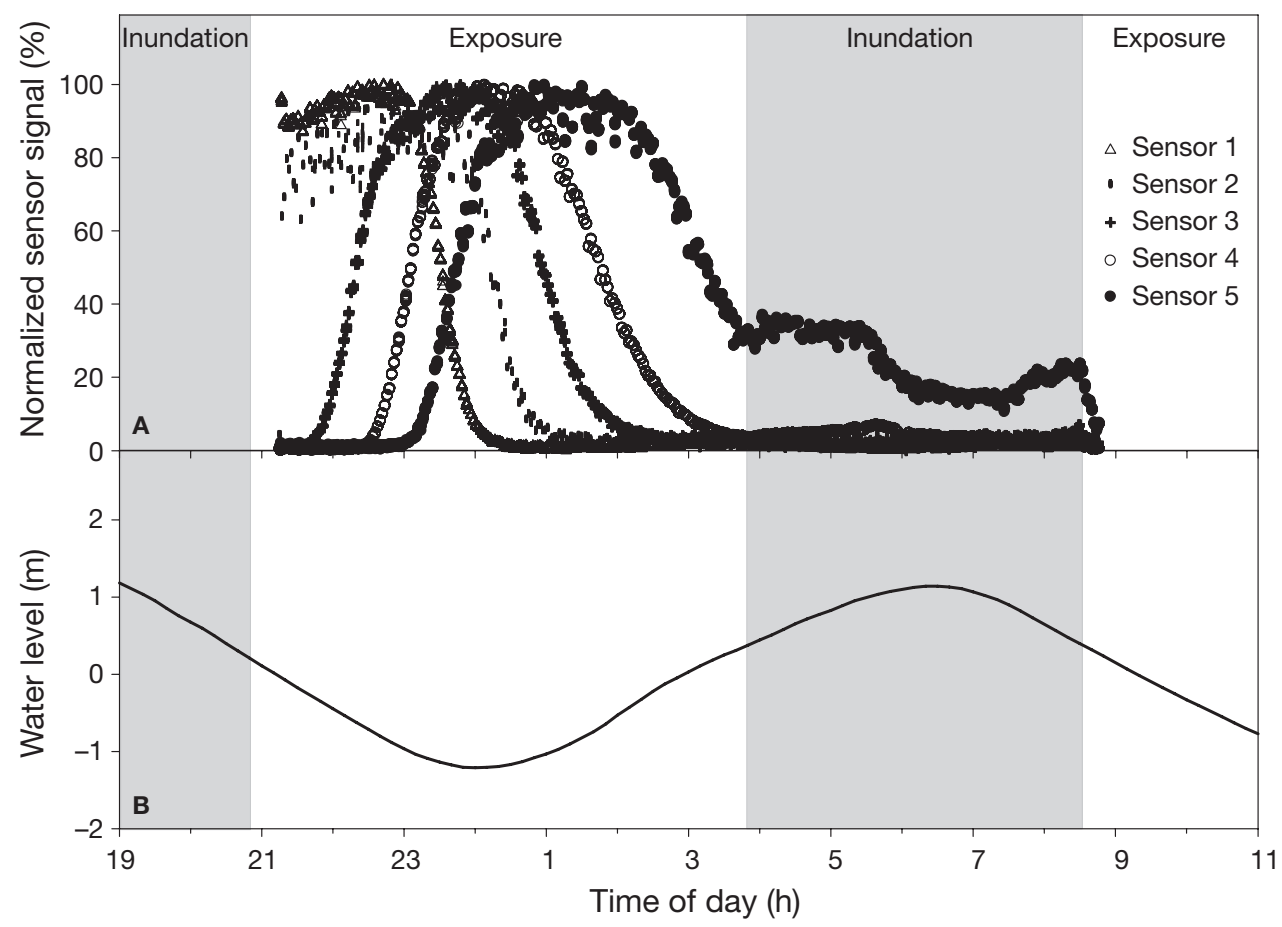

showed that the pore water flow ceased during submergence and resumed again after exposure. Other pore water flow measurements confirmed this finding (data not shown). During the March 2004 campaign, wind conditions resulted in up to $9 \mathrm{~h}$ long periods of exposure, compared to $7.5 \mathrm{~h}$ in July. Nevertheless, measured flow velocities in the upper $10 \mathrm{~cm}$ of the sediment $\left(0.54 \mathrm{~cm} \mathrm{~h}^{-1}\right)$ were less than during the July campaign. In March, pore water flow velocities were similar down to a sediment depth of $30 \mathrm{~cm}$, but decreased below this (Table 2). During both measuring campaigns, pore water flow velocities remained relatively constant for the duration of the exposure period. During most of the exposure period, puddles of water persisted on the almost level sediment surface $30 \mathrm{~m}$ upslope on the upper sand flat site (6 $\mathrm{cm}$ vertical gain), and no pore water flow could be detected during the first $6.5 \mathrm{~h}$ of exposure in March 2004. Pore water flow at $5 \mathrm{~cm}$ depth started within the last $2.5 \mathrm{~h}$ of exposure and coincided with a 'drying' of the sediment surface due to a gradual drop in the pore water table. In contrast, pore water flow was detected during the entire period of exposure in the steeper sloping, upper sand flat site.

\section{Pore water seepage}

Pore water was released from the sediment at the lower sand flat site during ebb tide, as quantified during the March 2004 campaign. At low tide, seepage was restricted to an area extending from the low water line to about 20 to $30 \mathrm{~m}$ up the slope, as indicated by its 'glassy' sediment surface. Discharge continued throughout the period of exposure. In 4 measurements with the open seepage meters, initial rates of seepage ranged between 0.7 and $3.0 \mathrm{l} \mathrm{m}^{-2} \mathrm{~h}^{-1}$, decreasing to 0.1-0.4 $\mathrm{l} \mathrm{m}^{-2} \mathrm{~h}^{-1}$ shortly before re-inundation (Fig. 7A). Measurements with the rhombic seepage meters recorded a comparable discharge. Nutrient concentrations of the discharged pore water increased over time for silicate, phosphate and ammonium, and decreased or remained constant for NOx (Fig. 7B). At similar rates of pore water seepage, the discharge of nutrients varied between measurements (Table 3).

\section{Pore water solute and seawater concentrations}

In July and March, we measured significant differences in the pore water nutrient and DIC concentrations between the upper and the lower Janssand sites (Wilcoxon-Mann-Whitney $U$-test, p $<0.001$ ). At the lower sand flat site, where water drained from the Janssand sediment, pore water silicate, phosphate and ammonium concentrations exceeded the respective concentrations at the upper flat by about 1 order of magnitude during both measuring campaigns (Fig. 8). Likewise, pore water DIC concentrations at the lower site were 2- to 5-fold higher than at the upper site in July, and 5 to 6-fold higher in March (Fig. 9), reaching $20 \mathrm{mmol} \mathrm{l}^{-1}$ during both campaigns. Pore water solute 


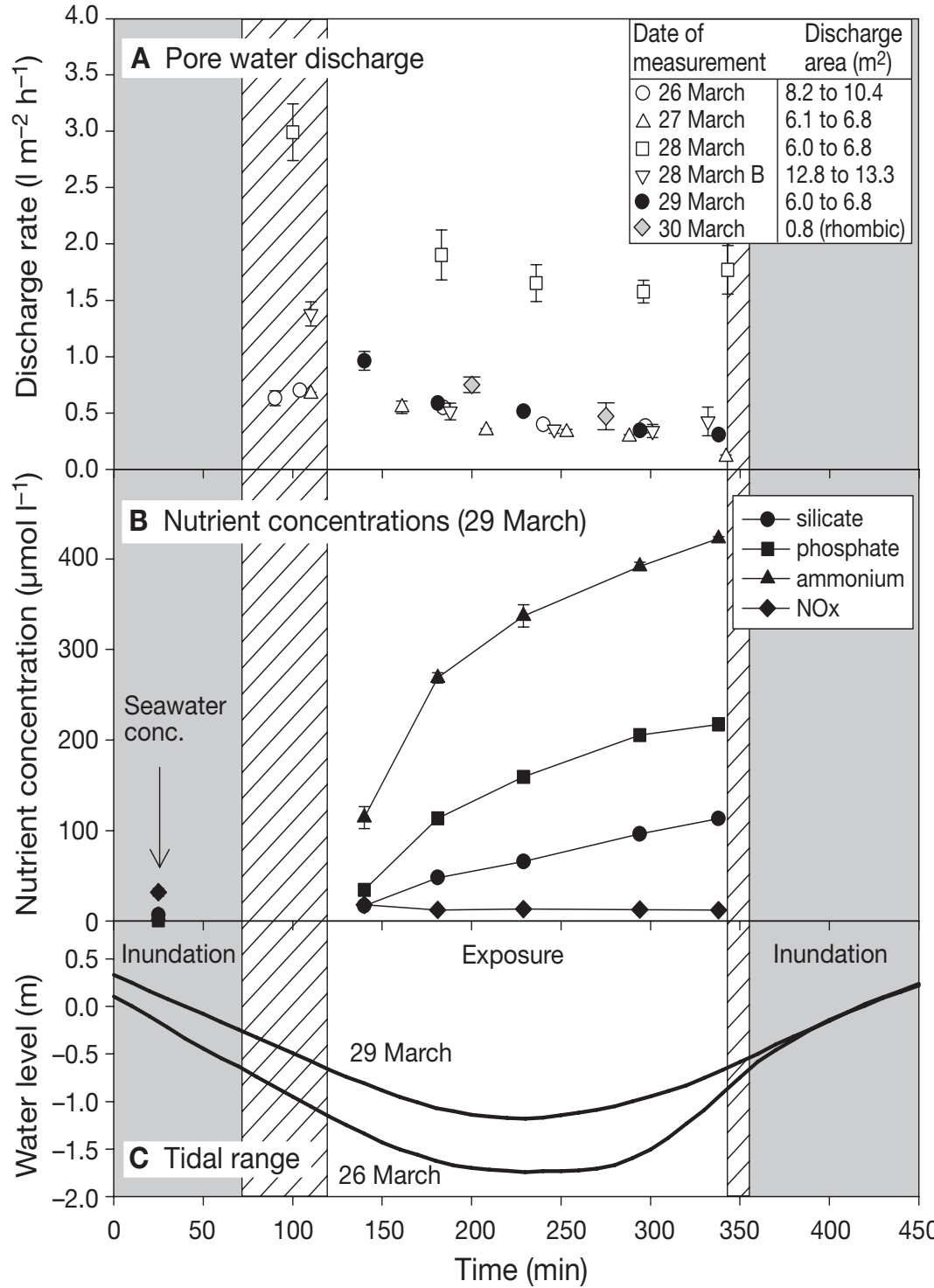

Fig. 7. (A) Mean $( \pm \mathrm{SD})$ seepage rates of pore water during low tide during 5 consecutive days at the lower sand flat $(n=10)$ and associated sampling discharge areas (inset). (B) Nutrient concentrations of discharged pore water corresponding to measurement of $29 \operatorname{March}\left(\bullet\right.$ in $\left.A_{i} n=3\right)$; all measurements were conducted within $20 \mathrm{~m}$ distance of each other and data are means $( \pm \mathrm{SD}) .(\mathrm{C})$ Lines mark minimum and maximum range of water level between 26 March and 30 March measurements based on mean sea level; shading: inundation period on tidal flat; hatched area: period of inundation or exposure (depending on tidal range) concentrations exceeded those of the ambient water by far (Table 4). Water column $\mathrm{C}: \mathrm{N}$ ratios of POM averaged between 6 and 7, indicating fresh organic matter. During July 2003, the chlorophyll a inventory in the upper $5 \mathrm{~cm}$ of the sediment was similar for the upper (11.2 $\left.\pm \mathrm{SD} 1.9 \mu \mathrm{g} \mathrm{g}^{-1}, \mathrm{n}=20\right)$ and lower $\left(10.4 \pm \mathrm{SD} 1.3 \mu \mathrm{g} \mathrm{g}^{-1}, \mathrm{n}=20\right)$ flat.

\section{Chamber flux measurements}

The bromide tracer was transported down to a sediment depth of 2 to $3 \mathrm{~cm}$, revealing advective flushing of the incubated permeable sediment (Table 5). At the upper sand flat, phosphate was released from the sediment, while silicate was consumed. Concentrations of ammonium, nitrate and nitrite stayed below detection limits. Fluxes of DIC and oxygen reflected photosynthetic activity. Oxygen was produced in the transparent chambers (1500 to $2000 \mu \mathrm{mol} \mathrm{m} \mathrm{m}^{-2} \mathrm{~h}^{-1}$ ) and consumed (1300 to $1600 \mu \mathrm{mol} \mathrm{m} \mathrm{m}^{-2} \mathrm{~h}^{-1}$ ) in the opaque chambers, corresponding to an average gross photosynthetic production of $3300 \mu \mathrm{mol} \mathrm{C} \mathrm{m}^{-2} \mathrm{~h}^{-1}$. At the lower sand flat site, pore water started seeping from the sediment after the upper Janssand became exposed during ebb tide. In order to assess the contribution of seepage to the total solute release in the chambers, fluxes measured during inundation of the lower flat ( 0 to $6.5 \mathrm{~h}$ ) were subtracted from the total fluxes recorded during the period of $1.5 \mathrm{~h}$ when the upper flat was exposed and seepage occurred at the lower site (6.5 to $8 \mathrm{~h}$ ) (Table 5). During the first $6.5 \mathrm{~h}$ of the lower sand flat incubation, effluxes of silicate, phosphate and ammonium were observed in all but 1 chamber (Fig. 10). Fluxes of silicate and phosphate were slightly higher and ammonium fluxes were largely increased compared to the upper sand flat

Table 3. Discharge rate of nutrients $\left(\mu \mathrm{mol} \mathrm{m} \mathrm{m}^{-2} \mathrm{~h}^{-1}\right)$ and seepage rate $\left(\mathrm{l} \mathrm{m}^{-2} \mathrm{~h}^{-1}\right)$ of pore water; average of 4 measurements during the March 2004 campaign. Values are means (range)

\begin{tabular}{|cccc|}
\hline & Nutrient discharge & & \multirow{2}{*}{ Seepage rate } \\
\cline { 3 - 4 } Shilicate & Phosphate & Ammonium & $3.59(1.19-3.70)$ \\
$0.94(0.34-1.57)$ & $0.13(0.04-0.20)$ & $724.45(449.31-924.50)$ & $0.38(0.11-0.67)$ \\
$100.76(66.97-117.69)$ & $196.15(90.14-262.15)$ & $205.55(163.86-230.76)$ & $1.98(1.58-2.99)$ \\
$10.23(9.25-11.25)$ & $19.97(12.64-24.84)$ & $140.61(109.95-172.66)$ & $0.60(0.34-1.38)$ \\
$29.06(16.11-34.46)$ & $63.59(33.08-81.68)$ & & $0.54(0.30-0.96)$ \\
\hline
\end{tabular}




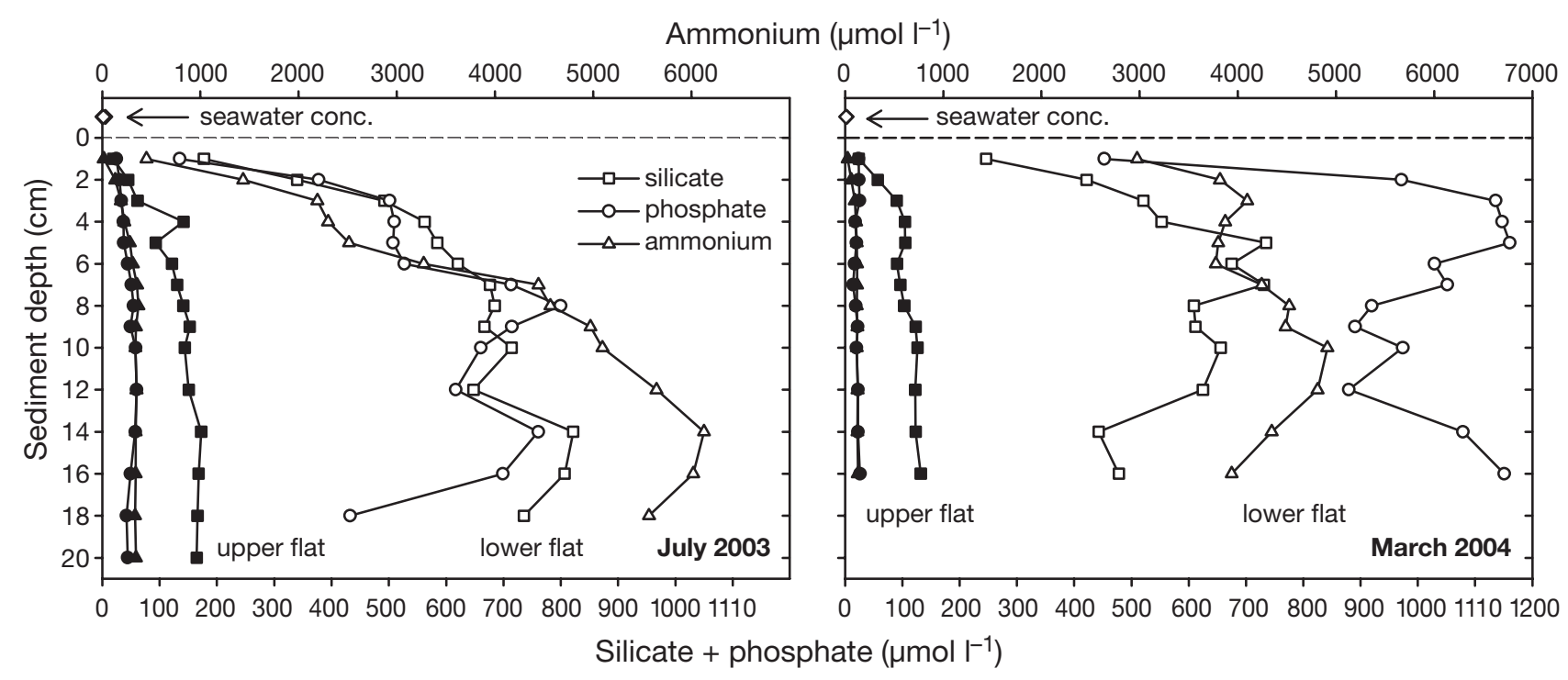

Fig. 8. Pore water concentrations of silicate, phosphate and ammonium in upper (filled symbols) and lower (open symbols) sand flat sites during July 2003 and March 2004. Concentrations in overlying seawater are shown above the dashed line

chamber measurements (Table 5). Concentrations for nitrate and nitrite always stayed below the detection limit. There was no visible influence of photosynthesis on oxygen fluxes (in contrast to the upper flat site (Wilcoxon-Mann-Whitney $U$-test, $\mathrm{p}<0.05)$ ), as oxygen was consumed to the same extent in dark and light chambers (Table 5). During the last $1.5 \mathrm{~h}$ (6.5 to $8 \mathrm{~h}$ ) of the lower sand flat incubations, a significantly increased efflux of reduced solutes $(p<0.05)$ could be observed in all chambers (for silicate in 4 chambers) suggesting that pore water was released from the submerged margin of the Janssand when the upper section of the flat became exposed (Table 5). The venting port of the chambers permitted release of seepage water into the chambers. Irrespective of dark or light incubations, silicate, phosphate and ammonium concentrations in the chamber waters increased at a higher rate during this period (Fig. 10). The efflux of DIC increased up to $87000 \mu \mathrm{mol} \mathrm{m} \mathrm{m}^{-2} \mathrm{~h}^{-1}$ compared to the

Table 4. Seawater characteristics at the study site during the March and July campaigns. Values are means $\pm \mathrm{SD}$

\begin{tabular}{|lcc|}
\hline Parameter & July 2003 & March 2004 \\
\hline Temperature $\left({ }^{\circ} \mathrm{C}\right)$ & $20.5-23.1$ & $5.6-8.4$ \\
Salinity & $31-32$ & $29-31$ \\
Silicate $\left(\mu m o l ~ ~^{-1}\right)$ & $5.91 \pm 0.51(\mathrm{n}=4)$ & $6.86 \pm 2.63(\mathrm{n}=4)$ \\
Phosphate $\left(\mu \mathrm{mol} \mathrm{l}^{-1}\right)$ & $1.80 \pm 0.27(\mathrm{n}=4)$ & $0.91 \pm 0.76(\mathrm{n}=4)$ \\
Ammonium $\left(\mu \mathrm{mol}^{-1}\right)$ & $0.21 \pm 0.07(\mathrm{n}=4)$ & $6.03 \pm 4.11(\mathrm{n}=4)$ \\
Nitrate $+{\mathrm{Nitrite}\left(\mu \mathrm{mol} \mathrm{l}^{-1}\right)}^{0.30 \pm 0.02(\mathrm{n}=4)}$ & $31.75 \pm 4.45(\mathrm{n}=4)$ \\
DIC $\left(\mu \mathrm{mol} \mathrm{l}^{-1}\right)$ & $2082.82 \pm 21.61(\mathrm{n}=4)$ & $2200.02(\mathrm{n}=1)$ \\
DOC $\left(\mathrm{mg} \mathrm{l}^{-1}\right)$ & $4.79 \pm 1.98(\mathrm{n}=5)$ & $2.59 \pm 1.48(\mathrm{n}=6)$ \\
POC $\left(\mathrm{mg} \mathrm{l}^{-1}\right)$ & $1.56 \pm 0.13(\mathrm{n}=2)$ & $2.47 \pm 0.06(\mathrm{n}=3)$ \\
PN $\left(\mathrm{mg} \mathrm{l}^{-1}\right)$ & $0.23 \pm 0.01(\mathrm{n}=2)$ & $0.31 \pm 0.03(\mathrm{n}=3)$ \\
\hline
\end{tabular}

initial $6.5 \mathrm{~h}$ period, and an increased consumption of oxygen in the opaque chambers was observed $(\mathrm{p}<$ 0.05). The fluxes of nutrients and DIC during the last $1.5 \mathrm{~h}$ exceeded the fluxes recorded prior to this period on average of 5 to 8 -fold. Advection of pore water into the chambers due to the interaction of the chambers with waves and currents (Shinn et al. 2002) could be ruled out as the cause for this increase, since no increased pore water discharge into the chambers was measured shortly after submergence of the tidal flat, when strong tidal currents were present.

\section{DISCUSSION}

Our study highlights a process unique to intertidal, permeable sediments: the periodic release of concentrated nutrients through pore water seepage. This release is caused by the exposure of the sediments during ebb tide, which sets up a hydraulic pressure gradient between the pore water level and the seawater level (Nielsen 1990). The pressure gradient causes water flow through permeable sediment layers toward the seepage zone at the margin of the tidal flat, where pore water is released into tidal gullies. Re-inundation of the flat during flooding eliminates the pressure gradient, thereby discontinuing the seepage. In the following discussion, we contrast sediment-water exchange in subtidal and intertidal sand beds and discuss the characteristics of drainage release and its potential implications. 


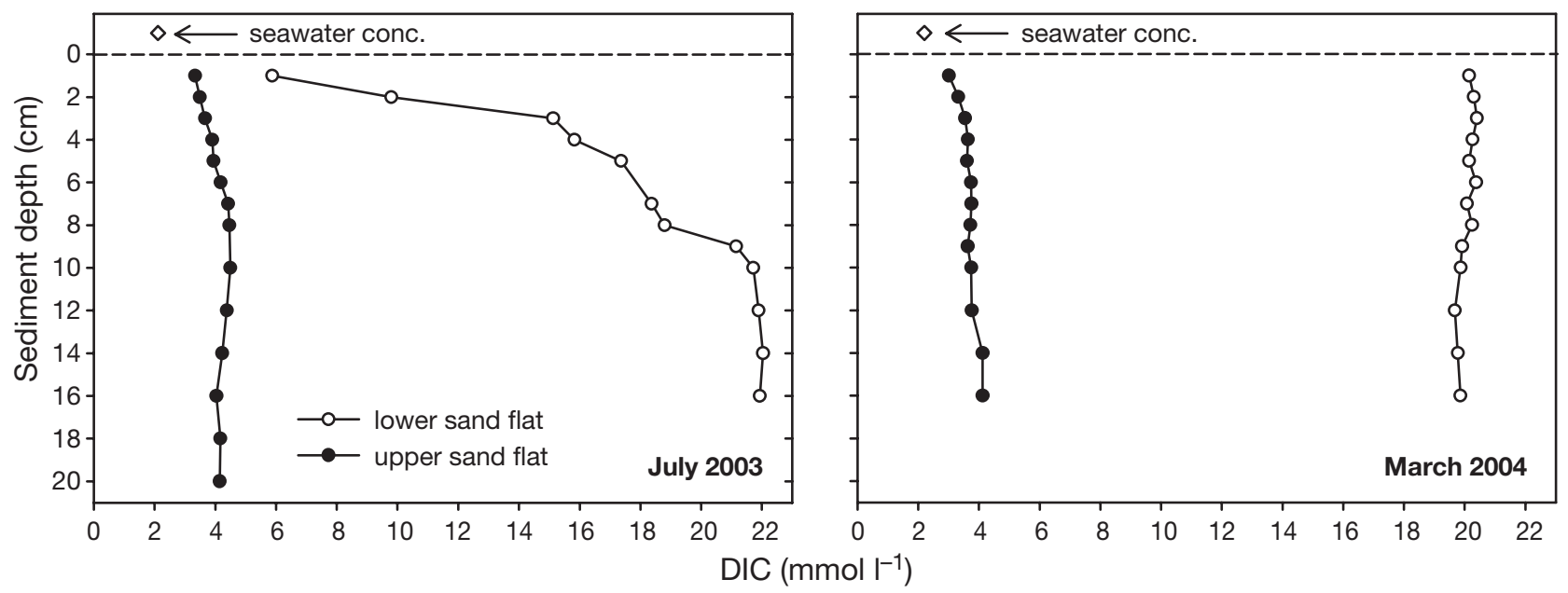

Fig. 9. Pore water dissolved inorganic carbon (DIC) concentration in upper (•) and lower (0) sand flat sites during July 2003 and March 2004. DIC concentration in overlying seawater is shown above dashed line

\section{Sediment-water exchange in intertidal versus subtidal zones}

Because of their draining mechanism, the sedimentwater exchange of matter in intertidal sand flats distinctly differs from that in constantly submerged marine deposits during parts of the tidal cycle. While submerged, diffusion, pore water advection, and bioturbation govern sediment-water exchange in both subtidal and intertidal sandy beds. With the onset of exposure of the intertidal sediment during ebb tide, however, the exchange mechanisms in these sediments change abruptly. With little or no water being present above most of the sediment, diffusive and advective release of sedimentary materials and the activities of bioirrigating macrofauna are reduced to a minimum. The continuing drop of the water level initiates a decline in the water level in the sediment. A slow but directed pore water flow sets in, carrying solutes and small particles along the increasing

Table 5. Effluxes (positive values) and influxes (negative values) in $\mu \mathrm{mol} \mathrm{m} \mathrm{m}^{-2} \mathrm{~h}^{-1}$ of nutrients, dissolved inorganic carbon (DIC) and oxygen in opaque and transparent chamber experiments conducted at the upper and lower sand flat sites in July 2003 (nd: not detectable). For fluxes calculated by linear regression, the $\mathrm{r}^{2}$ is given in parentheses. All other fluxes were calculated from start-end concentrations. Chamber fluxes (advection + faunal activity + diffusion + drainage [where applicable]) and drainage fluxes ([flux 6.5 to $8 \mathrm{~h}$ ] - [flux 0 to $6.5 \mathrm{~h}]$ ) are given as average of 6 chambers, except for the average upper sand flat DIC flux, which was calculated from dark incubations only

\begin{tabular}{|c|c|c|c|c|c|c|c|c|c|c|c|}
\hline Upper sand flat & & $\begin{array}{l}\text { Silicate } \\
0-4 \mathrm{~h}\end{array}$ & & $\begin{array}{c}\text { Phosphate } \\
0-4 \text { h }\end{array}$ & & $\underset{0-4 \mathrm{~h}}{\text { Ammonium }}$ & & $\begin{array}{c}\text { DIC } \\
0-4 \mathrm{~h}\end{array}$ & & $\begin{array}{c}\text { Oxygen } \\
0-4 \mathrm{~h}\end{array}$ & \\
\hline Opaque & $\begin{array}{l}1 \\
2 \\
3\end{array}$ & $\begin{array}{r}-47(0.70) \\
2(0.01) \\
-60(0.51)\end{array}$ & & $\begin{array}{l}10(0.30) \\
60(0.76) \\
28(0.28)\end{array}$ & & $\begin{array}{l}\text { nd } \\
\text { nd } \\
\text { nd }\end{array}$ & & $\begin{array}{l}4354(0.89) \\
6824(0.90) \\
2513(0.86)\end{array}$ & & $\begin{array}{l}-1290(0.95) \\
-1642(0.93) \\
-1469(0.91)\end{array}$ & \\
\hline Transparent & $\begin{array}{l}4 \\
5 \\
6\end{array}$ & $\begin{array}{l}-56(0.91) \\
-46(0.98) \\
-34(0.74)\end{array}$ & & $\begin{array}{c}\text { nd } \\
-5(0.56) \\
83(0.72)\end{array}$ & & $\begin{array}{l}\text { nd } \\
\text { nd } \\
\text { nd }\end{array}$ & & $\begin{array}{r}1223 \\
747 \\
4055\end{array}$ & & $\begin{array}{l}2050(0.95) \\
1930(0.90) \\
1493(0.90)\end{array}$ & \\
\hline Chamber flux & & -40 & & 29 & & & & 4564 & & & \\
\hline Lower sand flat & & $0-6.5 \mathrm{~h}$ & $6.5-8 \mathrm{~h}$ & $0-6.5 \mathrm{~h}$ & $6.5-8 \mathrm{~h}$ & $0-6.5 \mathrm{~h}$ & $6.5-8 \mathrm{~h}$ & $0-6.5 \mathrm{~h}$ & $6.5-8 \mathrm{~h}$ & $0-6.5 \mathrm{~h}$ & $6.5-8 \mathrm{~h}$ \\
\hline Opaque & $\begin{array}{l}1 \\
2 \\
3\end{array}$ & $\begin{array}{r}50(0.45) \\
285(0.99) \\
-42(1.00)\end{array}$ & $\begin{array}{r}-166 \\
2419 \\
275\end{array}$ & $\begin{array}{r}12(0.22) \\
309(0.97) \\
-1(0.05)\end{array}$ & $\begin{array}{r}178 \\
3070 \\
58\end{array}$ & $\begin{array}{r}92(0.68) \\
1144(0.98) \\
-18(0.31)\end{array}$ & $\begin{array}{r}576 \\
9449 \\
300\end{array}$ & $\begin{array}{r}1202(0.98) \\
12911(0.85) \\
2623(1.00)\end{array}$ & $\begin{array}{l}13792 \\
86993 \\
17740\end{array}$ & $\begin{array}{r}-697(0.95) \\
-862(0.92) \\
-1241(0.95)\end{array}$ & $\begin{array}{l}-1276(0.87) \\
-5042(0.98) \\
-3174(0.86)\end{array}$ \\
\hline Transparent & $\begin{array}{l}4 \\
5 \\
6\end{array}$ & $\begin{array}{r}35(0.47) \\
158(0.90) \\
108(0.76)\end{array}$ & $\begin{array}{r}836 \\
767 \\
-111\end{array}$ & $\begin{array}{r}55(0.65) \\
155(0.85) \\
78(0.91)\end{array}$ & $\begin{array}{r}794 \\
1265 \\
247\end{array}$ & $\begin{array}{l}391(0.73) \\
734(0.96) \\
497(0.96)\end{array}$ & $\begin{array}{r}3306 \\
3455 \\
986\end{array}$ & $\begin{array}{l}3199(0.89) \\
6949(0.96) \\
7540(0.98)\end{array}$ & $\begin{array}{l}28714 \\
36594 \\
36447\end{array}$ & $\begin{array}{l}-646(0.89) \\
-789(0.88) \\
-695(0.82)\end{array}$ & $\begin{array}{r}-660(0.54) \\
-1449(0.62) \\
-397(0.19)\end{array}$ \\
\hline $\begin{array}{l}\text { Chamber flux } \\
\text { Drainage flux }\end{array}$ & & 99 & $\begin{array}{l}670 \\
571\end{array}$ & 101 & $\begin{array}{l}935 \\
834\end{array}$ & 473 & $\begin{array}{l}3012 \\
2539\end{array}$ & 5737 & $\begin{array}{l}36713 \\
30976\end{array}$ & & \\
\hline
\end{tabular}


hydraulic gradient toward the lower rim of the flat and the drainage gullies. Here, pore water release zones develop, similar to those in sandy beaches when a quickly falling tide decouples from the slower falling pore water table (Nielsen 1990, Horn 2002). Material release (except gases) from the exposed intertidal flats, thus, becomes mainly restricted to the seepage zones, and here the observed fluxes were significantly higher than interfacial fluxes recorded during inundation.

Our chamber experiments indicate that pore water was discharged in submerged parts of the tidal flat as soon as a sufficient hydraulic gradient was present. The pronounced increase in nutrient and DIC concentrations in all submerged chambers deployed on the lower flat site after the elevated upper flat became exposed reflected increased discharge of nutrient-rich seepage water into the chambers (the venting port of the chambers permitted slow fluid exchange) (Fig. 10, Table 5). We can exclude that enhanced metabolic activity at the lower site was the cause for these observed increases, because oxygen consumption rates measured during the first $6.5 \mathrm{~h}$ of chamber incubations (Table 5) and sulfate reduction rates (Billerbeck et al. in press) were similar at both study sites. A similar discharge of pore water into benthic chambers caused by tidal water level fluctuations was reported by Jahnke et al. (2003) for an intertidal salt marsh.

\section{Different qualities of fluxes in submerged and exposed sediment}

While in the subtidal and submerged intertidal, sediment-water fluxes may reflect seasonal changes in organic matter loading, biological activity and hydrodynamical forcings (Kristensen et al. 1997, D'Andrea et al. 2002, de Beer et al. 2005), the compositional changes of the seepage fluxes during exposure are governed by the length and biogeochemical characteristics of the pathways the pore water follows through the sediment. Although the measured drainage fluid velocity (March $0.54 \mathrm{~cm} \mathrm{~h}^{-1}$, July $0.86 \mathrm{~cm} \mathrm{~h}^{-1}$ ) exceeded transport by molecular diffusion by some orders of magnitude, about 16 to 29 tidal cycles are needed for pore water to travel $1 \mathrm{~m}$ through the sediment. Organic materials progressively degrade during passage through the sediment, with degradation of buried organic matter (e.g. microphytobenthos, macroalgae) contributing to the solute inventory of the pore water flow (Ehrenhauss et al. 2004). This may explain why the DIC and nutrient concentrations in the seepage water exceeded those in the pore water of the upper $20 \mathrm{~cm}$ of the upper flat by factors of 10 to 15 . Furthermore, in contrast to the upper flat, the pore water nutrient and DIC concentrations of the lower flat did not show any seasonality, due to the long residence time, dispersion and mixing of the pore water in deeper layers of the tidal flat (Billerbeck et al. in press).

When integrated over areas exceeding several ripple wavelengths (few decimeters), the quality and quantity of solute fluxes from submerged sand beds is relatively homogeneous (Huettel 1990, Marinelli et al. 1998). In contrast, we observed large changes in the seepage solute concentrations draining from the exposed sand flat (Table 3). Draining of different sections and layers of the intertidal sand (while the water level falls and rises) produces variability in seepage water composition. Likewise, variation in fluxes between replicate chambers simultaneously deployed at the lower flat site suggests seepage heterogeneity on a relatively small spatial scale (Table 5). As a result of sediment heterogeneities (i.e. zones of different permeabilities), water flowed on preferential paths through the sand (Beven \& Germann 1982, Harvey et al. 1995, DiCarlo et al. 1999), which led to spatial variability of seepage in the release zone. This variability was also reflected by black spots ( $<50 \mathrm{~cm}$ diameter) in the seepage zone, produced by local release of sulfidic pore water. Discharge rates for most measurements in the seepage zone, however, were similar (Fig. 7) when seepage was integrated over larger sediment areas as done by our seepage collectors (6 to $13 \mathrm{~m}^{2}$ collection area).

\section{Origin of seepage water}

On average, 2.4 to $4.2 \mathrm{l} \mathrm{m}^{-2} \mathrm{~d}^{-1}$ of pore water was discharged on the lower sand flat site during spring and summer, respectively. The subsurface flows drained fluid from the sediment surface, water puddles that had remained on the surface gradually disappeared, and sections of the upper flat became visually 'dry'. The infiltration of surface water into the sediment carried oxygenated water (possibly $\mathrm{O}_{2}$-oversaturated due to strong benthic photosynthesis: Revsbech et al. 1980, Revsbech \& Jørgensen 1986), solutes and small particles into the sand (Huettel et al. 1998, Rusch et al. 2001, Ehrenhauss et al. 2004). Despite a continuous drop in the pore water level in the standpipes, the 'drying' of the sediment surface ceased with development of a water saturated capillary fringe (Gillham 1984, Turner \& Nielsen 1997), extending upward from the pore water table to the sediment surface (Drabsch et al. 1999, Atherton et al. 2001).

Persistent water saturation of the sediment surface, while pore water flows and seepage continued, suggested fueling of the pore flows either through other sources (e.g. groundwater: Simmons 1992, Moore 


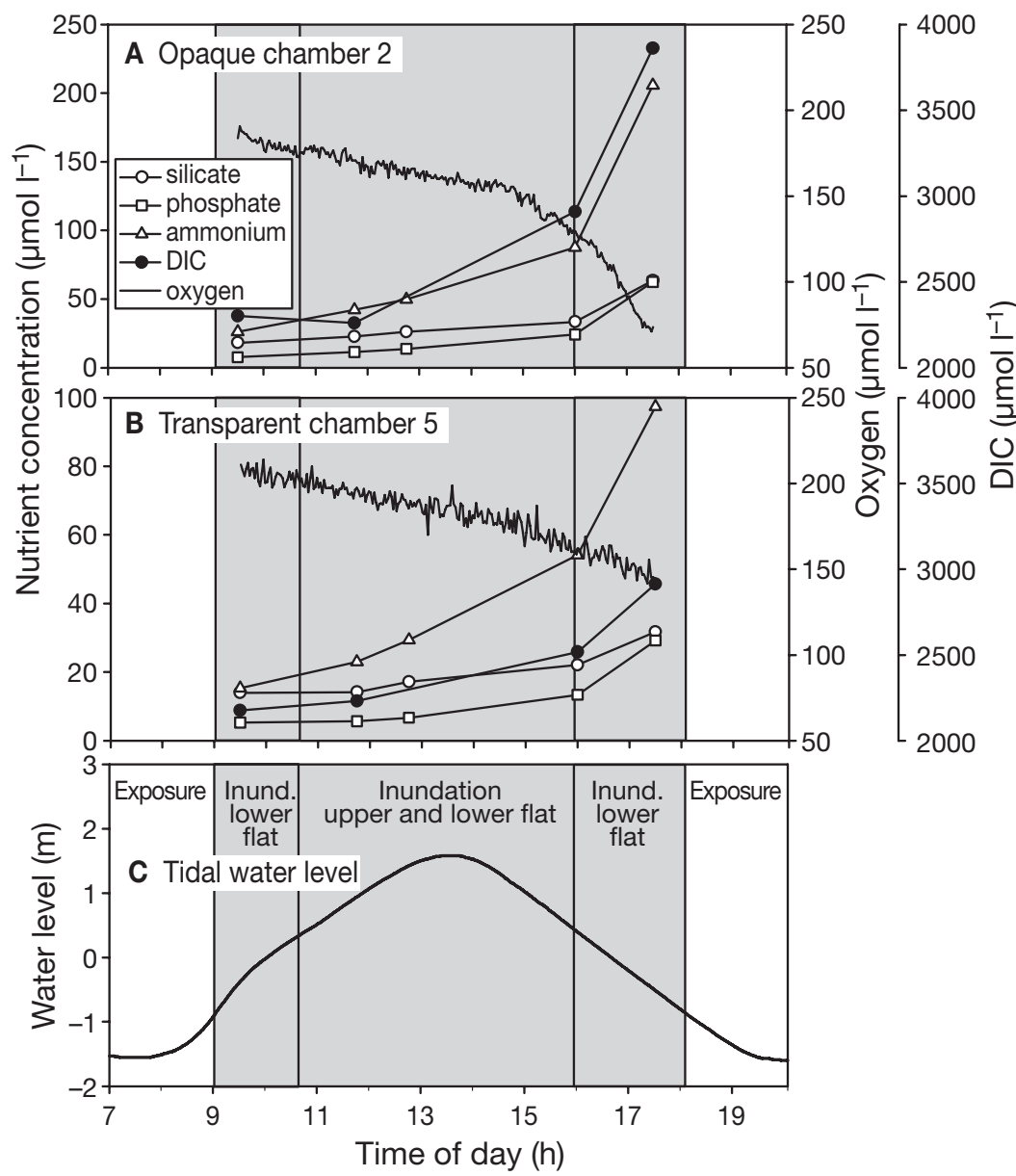

Fig. 10. Solute concentration changes at lower sand flat site measured in overlying water of (A) 1 opaque and (B) 1 transparent benthic chamber in July 2003. Shading marks the period of inundation for the upper and lower flats or lower flat only (delimited by vertical lines). (C) Tidal water level change based on mean sea level. Note the different scaling for nutrient concentrations in (A) and (B)

1996), or a gradual decrease in total tidal flat pore water volume through drainage. Terrestrial groundwater input is unlikely, since pore water chloride concentration remained nearly constant at seawater concentrations down to $4 \mathrm{~m}$ depth (Koelsch, pers. comm.) and salinity of the seepage water did not change. The gradual decrease in total pore water volume of the tidal flat without entrainment of air (which was never observed at the Janssand) would require shrinking of the tidal flat during exposure and subsequent swelling during inundation, resulting in small elevation changes of the tidal flat surface. Such oscillating changes in sediment elevation within a range of 1 to $3 \mathrm{~mm}$ due to changes in tidal water level have been detected in intertidal salt marshes (Paquette et al. 2004). We suggest that the seepage in Janssand also resulted in such pore volume changes, but that the resulting elevation changes would be smaller and difficult to detect. From each $1 \mathrm{~m}$ of the release zone (average $20 \mathrm{~m}$ wide), about 24 to 421 of pore water were discharged per tidal cycle during March and July, respectively. These volumes would correspond to a sediment elevation change of $0.5 \mathrm{~mm}$ for March and $0.8 \mathrm{~mm}$ for July, assuming this volume was drained from the approximately $50 \mathrm{~m}$ wide zone adjacent to the release zone, where we observed water infiltration into the sediment. During reinundation, partial release of the capillary tension may initiate expansion of the pore space with simultaneous uptake of water.

\section{Tidal filtration}

Uptake and release of water during a tidal cycle represents a filtration process that characterizes the Janssand as a large biocatalytic sand filter (Fig. 11). From pore water release rates and seepage nutrient concentrations, we can roughly estimate the total filtration and potentially associated mineralization for the investigated section of tidal flat. During March, about $1.2 \mathrm{l} \mathrm{m}^{-2}$ pore water was discharged each tidal cycle from the release zone of the sand flat, assuming an average exposure time of $2 \mathrm{~h}$ per tide for that zone. On a length of $3.5 \mathrm{~km}$ on the northern and northeastern boundary of the Janssand tidal flat (see Fig. 1), the topography and sediment is similar to those at our study site. With an average width of the release zone of $20 \mathrm{~m}$, a total of $168000 \mathrm{l}$ pore water was discharged each day from this area (ca. $70000 \mathrm{~m}^{2}$ ). In July, the drainage rates calculated based on the benthic chamber incubations were higher, producing on average $2.1 \mathrm{l} \mathrm{m}^{-2}$ tide $^{-1}$ (1.5 $\mathrm{h}$ discharge per tide) or a total discharge of $294000 \mathrm{l} \mathrm{d}^{-1}$ for the $3.5 \mathrm{~km}$ long Janssand section. Assuming degradation of organic matter with a composition close to the Redfield ratio, the nutrient discharge associated with seepage would correspond to an average mineralization of about $200 \mathrm{mg} \mathrm{m}^{-2}$ organic carbon $\mathrm{d}^{-1}$ during March (356 mg C $\mathrm{m}^{-2}$ based on $\mathrm{P}, 86 \mathrm{mg} \mathrm{C} \mathrm{m}^{-2}$ based on $\mathrm{N}$ ) and $1600 \mathrm{mg} \mathrm{C}$ $\mathrm{m}^{-2} \mathrm{~d}^{-1}$ during July (3183 $\mathrm{mg} \mathrm{C} \mathrm{m} \mathrm{m}^{-2} \mathrm{~d}^{-1}$ based on $\mathrm{P}$, $605 \mathrm{mg} \mathrm{C} \mathrm{m}^{-2} \mathrm{~d}^{-1}$ based on $\mathrm{N}, 1115 \mathrm{mg} \mathrm{C} \mathrm{m}^{-2} \mathrm{~d}^{-1}$ based on DIC). This corresponds to a roughly estimated yearly mineralization of $300 \mathrm{~g} \mathrm{C} \mathrm{m}^{-2} \mathrm{yr}^{-1}$. The observed low $\mathrm{N}: \mathrm{P}$ ratios (3 to 4) may have resulted from a loss of $\mathrm{NH}_{4}{ }^{+}$ through coupled nitrification/denitrification or release of $\mathrm{PO}_{4}$ from previously immobilized ironhydroxidecomplexes, ensuing in the release of anoxic pore waters. It must be borne in mind, however, that the main 


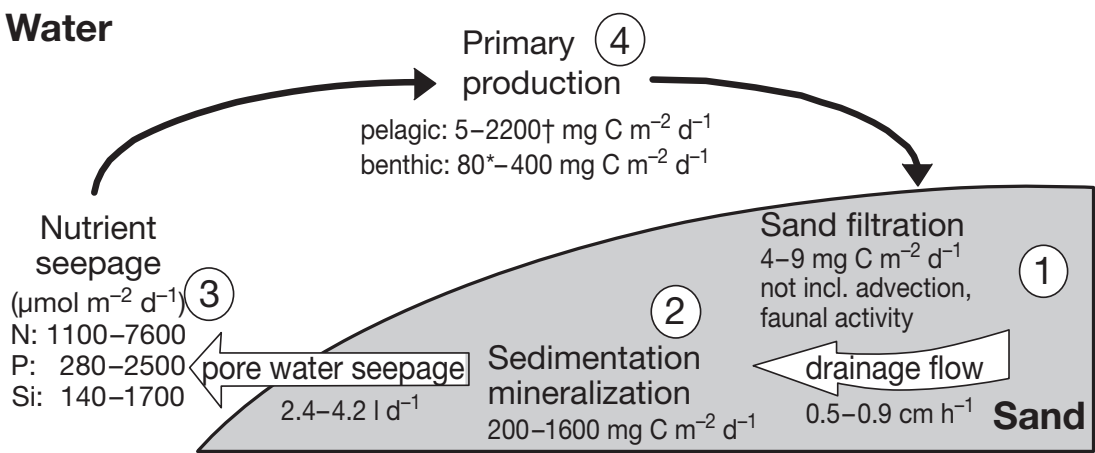

Fig. 11. Conceptual model of the Janssand filtration cycle. As a result of the hydraulic pressure gradient developing during low tide, water, suspended and dissolved matter infiltrates the sediment (1) and pore water flows through permeable sediment along the hydraulic gradient toward the tidal gully. Drainage flows transport substrates to the sedimentary microbial community, fueling mineralization (2) and carry metabolic products toward the seepage zone, where nutrient-enriched pore water is discharged (3). The seepage nutrients enhance primary production in the water column and on the sediments in the Wadden Sea (4). Replacement of discharged water volume with seawater during high tide filters organic matter into permeable sand (1) and the cycle starts anew. During inundation, additional organic matter is supplied to sediment by advection and faunal activity. *Billerbeck (unpubl., from March 2002); tgross water column production in the German Wadden Sea (from Tillmann et al. 2000)

body of the tidal flat acts as a seasonally independent nutrient source to the ecosystem through drainage (Billerbeck et al. in press). Therefore, the nutrients released from the lower flat may reflect mineralization processes occurring over long time spans and flow paths within the tidal flat. Nevertheless, the estimated mineralization rates are in the range of rates determined in both seasons for full tidal cycles on this tidal flat (967 and $2401 \mathrm{mg} \mathrm{C} \mathrm{m}^{-2} \mathrm{~d}^{-1}$ for March and July, respectively (Billerbeck et al. in press).

Extrapolated to the $3.5 \mathrm{~km}$ long region of the Janssand tidal flat, the pore water discharge would amount to a total required organic carbon mineralization of 6 to $25 \mathrm{~kg} \mathrm{~d}^{-1}$ during March and 42 to $223 \mathrm{~kg} \mathrm{~d}^{-1}$ during July, based on ammonium and phosphate discharge, respectively $\left(78.1 \mathrm{~kg} \mathrm{~d}^{-1}\right.$ based on DIC fluxes in July). Assuming that $100 \%$ of the DOC and $50 \%$ of the POC in the overlying seawater (Table 4 ) is transported into the sediment, about 4 to $9 \mathrm{mg} \mathrm{C} \mathrm{m}^{-2} \mathrm{~d}^{-1}$ are filtered into the $50 \mathrm{~m}$ wide infiltration zone as a consequence of drainage during March and July, respectively. This totals to $0.6 \mathrm{~kg}$ (March) or $1.6 \mathrm{~kg}$ (July) for the $3.5 \mathrm{~km}$ long Janssand section (175000 $\mathrm{m}^{2}$ infiltration area). These amounts can only account for a fraction of the mineralization required to produce the observed nutrient release. Fresh organic matter may be introduced to the sediment by advective infiltration during inundation (Huettel \& Rusch 2000) and by filtering, bioirrigating and bioturbating fauna (Graf \& Rosenberg 1997, Aller 2001). Buried mud lenses, such as those found in the lower flat, may be another source of organic matter and nutrients for this tidal flat. However, pore water nutrient concentrations did not reflect the location of these mud inclusions in the sediment cores. Probably the most important organic carbon source in this tidal flat is benthic primary production. Extrapolated to the total area of $245000 \mathrm{~m}^{2}$ of tidal flat that is influenced by infiltration and discharge, and assuming a $10 \mathrm{~h}$ light period during July, the average gross photosynthetic production of $3300 \mu \mathrm{mol}$ $\mathrm{C} \mathrm{m}^{-2} \mathrm{~h}^{-1}$ for the chamber incubations in the upper sand flat corresponds to a total organic carbon production of $97 \mathrm{~kg}$ $\mathrm{d}^{-1}$. This rough estimate can account for about half of the carbon mineralization required to match the observed nutrient export during summer, but benthic primary production should be even higher during exposure of the tidal flat (Pinckney \& Zingmark 1991).

Regardless of the origin of the organic matter, our estimate indicates that the Janssand intertidal flat does not accumulate organic matter, but releases mineralization products that can account for all the organic matter potentially filtered through the permeable beds by drainage during each tidal cycle, and for the material generated by benthic primary production. These findings suggest that these sands mineralize all organic matter that is introduced to the sediment, emphasizing their role as biocatalytic filter systems.

\section{Potential significance of seepage}

The pore water release locally affects the benthos and, on a larger spatial scale, the nutrient concentrations in the intertidal zone. In the vicinity of the seepage zone, the increased nutrient concentrations in the seepage water can support the benthic primary production; however, in July 2003, the chlorophyll a (chl a) inventory in the upper $5 \mathrm{~cm}$ of the sediment was similar for the upper and lower flat sites (10 to $11 \mu \mathrm{g} \mathrm{g}^{-1} \mathrm{chl} a$ at both sites). Adverse effects of the seepage water may have masked the positive influence of nutrient enrichment. During summer, when seepage sulfide reached $1 \mathrm{mmol} \mathrm{l}^{-1}$, the otherwise omnipresent diatoms were replaced by green flagellates and sulfide oxidizers (C.M. Burke \& D. de Beer pers. comm.), and Arenicola marina fecal mounds in the release zone decreased from $3.6 \mathrm{~m}^{-2}$ on the upper flat to $0.6 \mathrm{~m}^{-2}$ on the lower flat (6-fold). 


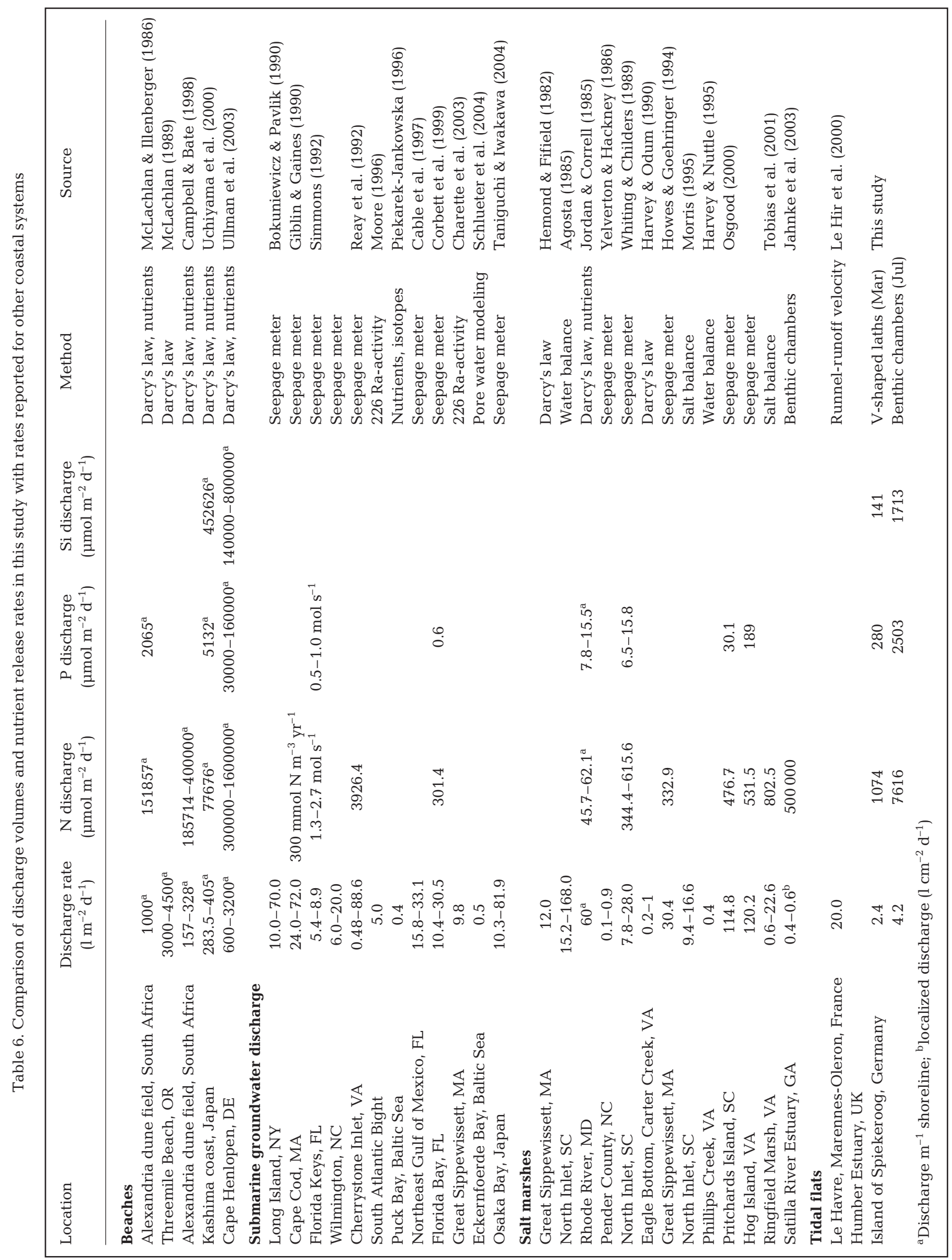


Most nutrients released through seepage are transported through the tidal gullies toward the North Sea (Niesel \& Günther 1999), where they can fuel primary production seaward of the barrier islands. Tidal currents transport the organic matter produced within these highly net autotrophic coastal waters back to the Wadden Sea, where it is mineralized (Postma 1954, van Beusekom et al. 1999). Because the seepage becomes most active only near maximum low tide and the average width of the sand flat belt along the southern coast of the North Sea is $13 \mathrm{~km}$ (van Beusekom \& de Jonge 2002), a large fraction of the nutrients will remain within the Wadden Sea, where they can enhance primary production of phytoplankton and microphytobenthos.

Thus, microalgal production, tidal flat filtration of this organic matter, mineralization within the intertidal sands and subsequent release of nutrients form a recycling loop, in which seepage plays an important role (Fig. 11). This coastal nutrient cycling resembles the mechanism of sediment-water column interaction proposed by Childers (1994) for salt marshes with tidal ranges exceeding $1 \mathrm{~m}$. In the Janssand, nutrient fluxes associated with the seepage exceeded by 5 - to 8 -fold those fluxes caused by the combined effects of diffusion, advection and bioirrigation during inundation. The ecological importance of groundwater or pore water discharge and the associated export of metabolic products to the water column has been emphasized in studies covering submarine groundwater discharge, wave dominated beaches and salt marshes (Table 6). However, only a few data are available on drainage for intertidal flats. Nutrient export from the Janssand through seepage surpassed the release rates reported in most other studies (Table 6), emphasizing the ecological importance of the seepage process in intertidal sands and the need for further, more detailed studies on this subject.

Acknowledgements. We thank Martina Alisch for the assistance with field and laboratory work and also acknowledge the hospitality and help of the Plattboden ship crews during the cruises. We also thank Gaby Schüssler, Susanne Menger, Daniela Franzke and Sindy Pabel for their help with laboratory work and Cäcilia Wigand for the preparation of the oxygen optodes. This study would not have been possible without the technical assistance of Jens Langreder, Axel Nordhausen, Georg Herz, Alfred Kutsche, Paul Färber, Volker Meyer, and Harald Osmers. Thomas Badewien of the ICBM in Oldenburg and Waldmar Anton of the WSA Emden kindly provided tide gauge data. We appreciate the valuable comments of Antje Boetius, Perran Cook, Stefan Jansen, and Christian Wild on the manuscript. The comments of Professor V. de Jonge and 4 anonymous referees greatly helped to improve the manuscript. This study was supported by the Deutsche Forschungsgemeinschaft (DFG) within the research group 'Biogeochemistry of the Wadden Sea' (FG 432-5), coordinated by Jürgen Rullkötter. We are grateful to Bo Barker Jørgensen and Michael Böttcher for their support of this work and coordination of the sub-project 'Biogeochemical processes at the sediment-water interface of intertidal sediments'.

\section{LITERATURE CITED}

Agosta K (1985) The effect of tidally induced changes in the creekbank water table on pore water chemistry. Estuar Coast Shelf Sci 21:389-400

Aller RC (2001) Transport and reactions in the bioirrigated zone. In: Boudreau BP, Jørgensen BB (eds) The Benthic Boundary Layer. Oxford University Press, Oxford, p 269-301

Atherton RJ, Baird AJ, Wiggs GFS (2001) Inter-tidal dynamics of surface moisture content on a meso-tidal beach. J Coast Res 17:482-489

Beven K, Germann P (1982) Macropores and water flow in soils. Water Resour Res 18:1311-1325

Billerbeck M, Werner U, Polerecky L, Walpersdorf E, de Beer D, Huettel $M$ (in press) Surficial and deep pore water circulation governs spatial and temporal scales of nutrient recycling in intertidal sand flat sediment. Mar Ecol Prog Ser

Bokuniewicz H, Pavlik B (1990) Groundwater seepage along a barrier-island. Biogeochemistry 10:257-276

Cable JE, Burnett WC, Chanton JP, Corbett DR, Cable PH (1997) Field evaluation of seepage meters in the coastal marine environment. Estuar Coast Shelf Sci 45:367-375

Campbell EE, Bate GC (1998) Tide-induced pulsing of nutrient discharge from an unconfined aquifer into an Anaulus australis-dominated surf-zone. Water S A 24:365-370

Charette MA, Splivallo R, Herbold C, Bollinger MS, Moore WS (2003) Salt marsh submarine groundwater discharge as traced by radium isotopes. Mar Chem 84:113-121

Childers DL (1994) Fifteen years of marsh flumes: a review of marsh-water column interactions in southeastern USA estuaries. In: Mitsch WJ (ed) Global wetlands: old world and new. Elsevier, Amsterdam, p 277-293

Corbett DR, Chanton J, Burnett W, Dillon K, Rutkowski C, Fourqurean JW (1999) Patterns of groundwater discharge into Florida Bay. Limnol Oceanogr 44:1045-1055

D'Andrea AF, Aller RC, Lopez GR (2002) Organic matter flux and reactivity on a South Carolina sandflat: the impacts of porewater advection and macrobiological structures. Limnol Oceanogr 47:1056-1070

de Beer D, Wenzhöfer F, Ferdelman TG, Boehme SE and 5 others (2005) Transport and mineralization rates in North Sea sandy intertidal sediments, Sylt-Rømø Basin, Wadden Sea. Limnol Oceanogr 50:113-127

DiCarlo DA, Bauters TWJ, Darnault CJG, Steenhuis TS, Parlange JY (1999) Lateral expansion of preferential flow paths in sands. Water Resour Res 35:427-434

Drabsch JM, Parnell KE, Hume TM, Dolphin TJ (1999) The capillary fringe and the water table in an intertidal estuarine sand flat. Estuar Coast Shelf Sci 48:215-222

Ehrenhauss S, Witte U, Bühring SL, Huettel M (2004) Effect of advective pore water transport on distribution and degradation of diatoms in permeable North Sea sediments. Mar Ecol Prog Ser 271:99-111

Flemming BW, Ziegler K (1995) High-resolution grain size distribution patterns and textural trends in the backbarrier environment of Spiekeroog Island (southern North Sea). Senckenb Marit 26:1-24

Forster S, Glud RN, Gundersen JK, Huettel M (1999) In situ study of bromide tracer and oxygen flux in coastal sediments. Estuar Coast Shelf Sci 49:813-827 
Giblin AE, Gaines AG (1990) Nitrogen inputs to a marine embayment-the importance of groundwater. Biogeochemistry 10:309-328

Gillham RW (1984) The capillary-fringe and its effect on water-table response. J Hydrol (Anst) 67:307-324

Graf G, Rosenberg R (1997) Bioresuspension and biodeposition: a review. J Mar Syst 11:269-278

Grasshoff K, Kremling K, Ehrhardt M (1999) Methods of seawater analysis. Wiley-VCH, Berlin

Hall POJ, Aller RC (1992) Rapid, small-volume, flow injection analysis for $\Sigma \mathrm{CO}_{2}$ and $\mathrm{NH}_{4}{ }^{+}$in marine and freshwaters. Limnol Oceanogr 37:1113-1119

Harvey JW, Nuttle WK (1995) Fluxes of water and solute in a coastal wetland sediment. 2. Effect of macropores on solute exchange with surface water. J Hydrol 164:109-125

Harvey JW, Odum WE (1990) The influence of tidal marshes on upland groundwater discharge to estuaries. Biogeochemistry 10:217-236

Harvey JW, Chambers RM, Hoelscher JR (1995) Preferential flow and segregation of porewater solutes in wetland sediment. Estuaries 18:568-578

Hemond HF, Fifield JL (1982) Subsurface flow in salt-marsh peat - a model and field-study. Limnol Oceanogr 27:126-136

Hertweck G (1995) Distribution patterns of characteristic sediment bodies and benthos populations in the Spiekeroog backbarrier tidal flat area, southern North Sea. 1. Results of a survey of tidal flat structure. 1988-1992 Senckenb Marit 26:81-94

Holst G, Glud RN, Kühl M, Klimant I (1997) A microoptode array for fine-scale measurement of oxygen distribution. Sensors Actuators B 38:122-129

Horn DP (2002) Beach groundwater dynamics. Geomorphology 48:121-146

Howes BL, Goehringer DD (1994) Porewater drainage and dissolved organic carbon and nutrient losses through the intertidal creekbanks of a New England salt marsh. Mar Ecol Prog Ser 114:289-301

Huettel M (1990) Influence of the lugworm Arenicola marina on porewater nutrient profiles of sand flat sediments. Mar Ecol Prog Ser 62:241-248

Huettel M, Gust G (1992) Solute release mechanism from confined sediment cores in stirred benthic chambers and flume flows. Mar Ecol Prog Ser 82:187-197

Huettel M, Rusch A (2000) Transport and degradation of phytoplankton in permeable sediment. Limnol Oceanogr 45:534-549

Huettel M, Ziebis W, Forster S (1996) Flow-induced uptake of particulate matter in permeable sediments. Limnol Oceanogr 41:309-322

Huettel M, Ziebis W, Forster S, Luther GW (1998) Advective transport affecting metal and nutrient distributions and interfacial fluxes in permeable sediments. Geochim Cosmochim Acta 62:613-631

Huettel M, Røy H, Precht E, Ehrenhauss S (2003) Hydrodynamical impact on biogeochemical processes in aquatic sediments. Hydrobiologia 494:231-236

Jahnke RA, Alexander CR, Kostka JE (2003) Advective pore water input of nutrients to the Satilla River Estuary, Georgia, USA. Estuar Coast Shelf Sci 56:641-653

Jordan TE, Correll DL (1985) Nutrient chemistry and hydrology of interstitial water in brackish tidal marshes of Chesapeake Bay. Estuar Coast Shelf Sci 21:45-55

Klimant I, Meyer V, Kühl M (1995) Fiberoptic oxygen microsensors, a new tool in aquatic biology. Limnol Oceanogr 40:1159-1165

Kristensen E, Jensen MH, Jensen KM (1997) Temporal variations in microbenthic metabolism and inorganic nitrogen fluxes in sandy and muddy sediments of a tidally dominated bay in the northern Wadden Sea. Helgol Mar Res 51:295-320

Kuwae T, Hosokawa Y, Eguchi N (1998) Dissolved inorganic nitrogen cycling in Banzu intertidal sand-flat, Japan. Mangroves Salt Marshes 2:167-175

Le Hir P, Roberts W, Cazaillet O, Christie M, Bassoullet P, Bacher C (2000) Characterization of intertidal flat hydrodynamics. Cont Shelf Res 20:1433-1459

Lorenzen CJ (1967) Determination of chlorophyll and pheopigments: spectrophotometric equations. Limnol Oceanogr 12:343-346

Marinelli RL, Jahnke RA, Craven DB, Nelson JR, Eckman JE (1998) Sediment nutrient dynamics on the South Atlantic Bight continental shelf. Limnol Oceanogr 43:1305-1320

McLachlan A (1989) Water filtration by dissipative beaches. Limnol Oceanogr 34:774-780

McLachlan A, Illenberger W (1986) Significance of groundwater nitrogen input to a beach surf zone ecosystem. Stygologia 2:291-296

Moore WS (1996) Large groundwater inputs to coastal waters revealed by Ra-226 enrichments. Nature 380:612-614

Morris JT (1995) The mass-balance of salt and water in intertidal sediments - Results from North-Inlet, South Carolina. Estuaries 18:556-567

Nielsen P (1990) Tidal dynamics of the water table in beaches. Water Resour Res 26:2127-2134

Niesel V, Günther CP (1999) Distribution of nutrients, algae and zooplankton in the Spiekeroog backbarrier system. In: Dittmann S (ed) The Wadden Sea ecosystem - stability properties and mechanisms. Springer-Verlag, Berlin, p 77-94

Osgood DT (2000) Subsurface hydrology and nutrient export from barrier island marshes at different tidal ranges. Wetlands Ecol Manag 8:133-146

Paquette $\mathrm{CH}$, Sundberg $\mathrm{KL}$, Boumans RMJ, Chmura GL (2004) Changes in saltmarsh surface elevation due to variability in evapotranspiration and tidal flooding. Estuaries 27:82-89

Piekarek-Jankowska H (1996) Hydrochemical effects of submarine groundwater discharge to the Puck Bay (Southern Baltic Sea, Poland). Geogr Polon 67:103-119

Pilditch CA, Emerson CW, Grant J (1997) Effect of scallop shells and sediment grain size on phytoplankton flux to the bed. Cont Shelf Res 17:1869-1885

Pinckney J, Zingmark RG (1991) Effects of tidal stage and sun angles on intertidal benthic microalgal productivity. Mar Ecol Prog Ser 76:81-89

Postma H (1954) Hydrography of the Dutch Wadden Sea. Arch Néerl Zool 10:405-511

Precht E, Huettel M (2004) Rapid wave-driven advective pore water exchange in a permeable coastal sediment. J Sea Res 51:93-107

Reay WG, Gallagher DL, Simmons GM (1992) Groundwater discharge and its impact on surface-water quality in a Chesapeake Bay inlet. Water Resour Bull 28:1121-1134

Revsbech NP, Jørgensen BB (1986) Microelectrodes: their use in microbial ecology. In: Marshall KC (ed) Advances in microbial ecology. Vol 9. Plenum Press, London, p 293-352

Revsbech NP, Sorensen J, Blackburn TH, Lomholt JP (1980) Distribution of oxygen in marine sediments measured with microelectrodes. Limnol Oceanogr 25:403-411

Rusch A, Forster S, Huettel M (2001) Bacteria, diatoms and detritus in an intertidal sandflat subject to advective transport across the water-sediment interface. Biogeochemistry 55:1-27 
Schlüter M, Sauter EJ, Andersen CE, Dahlgaard H, Dando PR (2004) Spatial distribution and budget for submarine groundwater discharge in Eckernförde Bay (Western Baltic Sea). Limnol Oceanogr 49:157-167

Shinn EA, Reich CD, Hickey TD (2002) Seepage meters and Bernoulli's revenge. Estuaries 25:126-132

Simmons GM Jr (1992) Importance of submarine groundwater discharge (SGWD) and seawater cycling to material flux across sediment/water interfaces in marine environments. Mar Ecol Prog Ser 84:173-184

Sundbäck K, Miles A, Göransson E (2000) Nitrogen fluxes, denitrification and the role of microphytobenthos in microtidal shallow-water sediments: an annual study. Mar Ecol Prog Ser 200:59-76

Taniguchi M, Iwakawa H (2004) Submarine groundwater discharge in Osaka Bay, Japan. Limnology 5:25-32

Tillmann U, Hesse KJ, Colijn F (2000) Planktonic primary production in the German Wadden Sea. J Plankton Res 22:1253-1276

Tobias CR, Harvey JW, Anderson IC (2001) Quantifying groundwater discharge through fringing wetlands to estuaries: seasonal variability, methods comparison, and implications for wetland-estuary exchange. Limnol Oceanogr 46:604-615

Turner IL, Nielsen P (1997) Rapid water table fluctuations within the beach face-implications for swash zone sediment mobility. J Coast Engin 32:45-59

Uchiyama Y, Nadaoka K, Rolke P, Adachi K, Yagi H (2000) Submarine groundwater discharge into the sea and asso-

Editorial responsibility: Howard I. Browman (Associate Editor-in-Chief), Storebø, Norway ciated nutrient transport in a sandy beach. Water Resour Res 36:1467-1479

Ullman WJ, Chang B, Miller DC, Madsen JA (2003) Groundwater mixing, nutrient diagenesis, and discharges across a sandy beachface, Cape Henlopen, Delaware (USA). Estuar Coast Shelf Sci 57:539-552

Usui T, Koike I, Ogura N (1998) Tidal effect on dynamics of pore water nitrate in intertidal sediment of a eutrophic estuary. J Oceanogr 54:205-216

van Beusekom JEE, de Jonge VN (2002) Long-term changes in Wadden Sea nutrient cycles: importance of organic matter import from the North Sea. Hydrobiologia 475: 185-194

van Beusekom JEE, Brockmann UH, Hesse KJ, Hickel W, Poremba K, Tillmann U (1999) The importance of sediments in the transformation and turnover of nutrients and organic matter in the Wadden Sea and German Bight. Dtsch Hydrogr Z 51:245-266

Whiting GJ, Childers DL (1989) Subtidal advective water flux as a potentially important nutrient input to southeastern USA saltmarsh estuaries. Estuar Coast Shelf Sci 28:417-431

Yelverton GF, Hackney CT (1986) Flux of dissolved organic carbon and pore water through the substrate of a Spartina alterniflora marsh in North Carolina. Estuar Coast Shelf Sci 22:255-267

Ziebis W, Huettel M, Forster S (1996) Impact of biogenic sediment topography on oxygen fluxes in permeable sediments. Mar Ecol Prog Ser 140:227-237

Submitted: September 16, 2005; Accepted: March 7, 2006 Proofs received from author(s): June 6, 2006 